\title{
Less is more. Adjusting the taxonomy of the polytypic Mimosa setosa (Leguminosae, Mimosoid)
}

\author{
Leonardo Maurici Borges ${ }^{1,2,4}$, Marcelo Fragomeni Simon ${ }^{3}$ \& José Rubens Pirani ${ }^{2}$
}

\begin{abstract}
Mimosa setosa, as currently circumscribed, is a polytypic species comprising four subspecies and eight varieties. Recent phylogenetic analyses showed that these infraspecific taxa do not form a monophyletic group. A morphological analysis of a complete set of specimens gathered from several herbaria, including types and recent collections, combined with the application of the Phylogenetic Species Concept lead to recognition of taxa currently placed under $M$. setosa as six different species with no infraspecific taxa recognised. Congruence among phylogenetic data, geography and use of the specific rank as the least inclusive unity for description allows for better comparison of biological diversity and an improved circumscription of taxa in the $M$. setosa complex.

Key words: Brazil, campo rupestre, cerrado, Fabaceae, Phylogenetic Species Concept.

Resumo

Mimosa setosa, em sua circunscrição atual, é uma espécie politípica que inclui quatro subespécies e oito variedades. Estudos filogenéticos recentes indicam que esses táxons infraespecíficos não formam um grupo monofilético. A análise morfológica de um conjunto de espécimes obtidos em diversos herbários, incluindo tipos e coletas recentes, associada à aplicação do Conceito Filogenético de espécie permite desmembrar $M$. setosa em seis diferentes espécies sem táxons infraespecíficos. Congruência entre dados filogenéticos, geografia e adoção do nível de espécie como a unidade mínima para descrição de táxons permite uma melhor comparação da diversidade biológica e uma circunscrição mais adequada dos táxons envolvidos no complexo M. setosa. Palavras-chave: Brasil, campo rupestre, cerrado, Fabaceae, Conceito Filogenético de espécie.
\end{abstract}

\section{Introduction}

With approximately 550 species, Mimosa Linnaeus (1753: 516) is one of the largest genera in Mimosoid clade of the Leguminosae (Barneby 1991; Luckow 2005; Simon et al. 2011). Most species occur in Tropical America, but a few are found in Africa and Asia (Barneby 1991; Villiers 2002). In the Americas, Brazil is a key area for studies in the genus, since 358 species are found in the country, 265 of which are endemic (BFG 2015). Although morphologically variable, the genus can be broadly defined by the presence of a craspedium-like fruit (Barneby 1991) and, within the diplo- or haplostemonous mimosoids, by the almost ubiquitous lack of extrafloral nectaries, which are present only in a small group of 15 species (Barneby 1991; Simon et al. 2011).

The taxonomy of Mimosa is based on the monumental work of Barneby (1991), the first and single most comprehensive revision produced after the treatments of Bentham (1841, 1842, 1845, 1846, 1875, 1876). Barneby's (1991) classification is striking in its recognition of many infraspecific taxa, both subspecies and varieties, although in a few species, only varieties are recognized (e.g., M. claussenii Bentham [1842]; M. aurivillus Martius [1838]).

\footnotetext{
${ }^{1}$ Universidade Federal de São Carlos, Depto. Botânica, Rod. Washington Luís Km 235, 13565-905, São Carlos, SP, Brazil.

${ }^{2}$ Universidade de São Paulo, Depto. Botânica, R. do Matão 277, 05508-090, São Paulo, SP, Brazil.

${ }^{3}$ Embrapa Recursos Genéticos e Biotecnologia, PqEB, C.P. 02372, 70770-917, Brasília, DF, Brazil.

${ }^{4}$ Author for correspondence: aquitemcaqui@gmail.com
} 
Table 1 - Taxa recognized within the Mimosa setosa complex by Bentham (1842, 1876), Barneby's (1991) and herein $=$ indicates synonymization of taxa.

\begin{tabular}{|c|c|c|}
\hline Bentham & Barneby & Herein \\
\hline & M. setosa subsp. setosa & \\
\hline \multirow[t]{2}{*}{ M. setosa } & var. setosa & M. setosa \\
\hline & var. pseudomelas & $=M \cdot$ setos $a$ \\
\hline \multirow[t]{3}{*}{ M. setosa var. nitens } & var. nitens & M. neonitens \\
\hline & var. rupigena & M. rupigena \\
\hline & M. setosa subsp. paludosa & \\
\hline \multirow[t]{6}{*}{ M. paludosa } & var. paludosa & M. paludosa \\
\hline & var. metadenotricha & $=M \cdot$ paludosa \\
\hline & M. setosa subsp. urbica & \\
\hline & var. urbica & M. urbica \\
\hline & var. urbana & $=$ M. urbica \\
\hline & M. setosa subsp. granitica & M. granitica \\
\hline
\end{tabular}

Mimosa setosa Bentham (1842) is among the many polytypic species recognized by Barneby (1991). Because of the lack of specimens with fruits, this species was initially ascribed by Bentham (1845) to Mimosa ser. Pachycarpae Benth., which is characterized by the presence of unjointed craspedia. However, the species currently belongs to M. ser. Setosae Barneby (1991), which was created mainly to accommodate species from $M$. ser. Pachycarpae that in fact have typical craspedial fruits.

Mimosa setosa comprises four subspecies, three of them with varieties, which are largely differentiated by the presence or absence of aculei, as well as by characteristics of the indumentum (Barneby 1991). Barneby (1991) based his infraspecific classification on the aggregation, and eventual subsuming, of three previously described taxa (M. paludosa Bentham [1842], M. setosa, and M. setosa var. nitens Bentham [1876], and added the description of new infraspecific taxa (e.g., $M$. setosa var. rupigena Barneby [1991]). Table 1 summarizes the ranks of those taxa in the treatmens of Bentham (1842, 1876) and Barneby (1991).

Mimosa setosa is distributed along altitudinal areas in the Brazilian Cerrado Domain, with many of its infraspecific taxa being allopatric micro-endemics. A few exceptions are observed, such as the co-occurrence of M. setosa var. setosa and M. setosa subsp. urbica Barneby (1991) and its varieties, as well as $M$. setosa var. paludosa (Benth.) Barneby (1991), which is sympatric with all the other varieties of $M$. setosa because of its wide distribution range.
Barneby (1991) considered his circumscription of Mimosa setosa as more comprehensive in that it was based on the examination of a large number of specimens, mostly not available to Bentham during his work with Mimosa. To Barneby, the morphological variability of the specimens could be best understood as an expression of variation along the geographical distribution of the plants. Hence, those morphotypes could be recognized at infraspecific level (Barneby 1991: 353).

Simon et al. (2011) showed that Mimosa ser. Setosae and M. ser. Pachycarpae together form a monophyletic group, and that the two series could not be distinguished from each other. Also, by sampling of two varieties of $M$. setosa, namely $M$. setosa var. paludosa and M. setosa var. urbica, it was concluded that the species is not monophyletic. Although it has been used as a criterion for delimitation of species (see Luckow 1995), monophyly does not necessarily apply at this level of biological hierarchy (Hennig 1968). Nonetheless, reciprocal illumination is still a valid procedure for evaluation of results and, in this sense, finding that two named varieties of the same species do not cluster together in a phylogenetic analysis may be indicative of inappropriate rank selection.

The analysis of specimens accumulated in herbaria after more than 20 years following Barneby's monograph, associated with study of populations in the field, and coupled with recent phylogenetic analyses (Borges 2014), reinforces the notion that the morphological features previously used to circumscribe infraspecific taxa in Mimosa 
setosa can better be used to diagnose species. Hence, we herein propose a new classification for those taxa previously placed by Barneby (1991) as infraspecific taxa of Mimosa setosa.

\section{Materials \& Methods}

Species concept

We review the taxonomy of Mimosa setosa, adopting the Phylogenetic Species Concept, which defines species "as the smallest aggregation of (sexual) populations or (asexual) lineages diagnosable by a unique combination of character states" (Wheeler \& Platnick 2000; see also Nixon \& Wheeler 1990). Contrary to suggestions by McDade (1995) and adopted by Henderson (2004; 2005a; 2005b; 2011), species are treated as the least inclusive taxonomic level and, thus, no infraspecific taxa are recognized here.

\section{Species delimitation}

Species were delimited based on external morphology following an adaptation of the "population aggregation analysis" method of Davis \& Nixon (1992) aiming to test Barneby's (1991) taxon concept for Mimosa setosa. Instead of using populations, the initial clusters of individuals were the infraspecific taxa recognized by Barneby (1991) within $M$. setosa and closely morphologically similar taxa, namely $M$. melanocarpa Bentham (1875), considered akin to M. setosa (Barneby 1991), M. occidentalis var. novo-galiciana Barneby (1991), treated as a synonym of $M$. setosa var. paludosa by Grether (2000) and M. serpensetosa L.M.Borges (Borges et al. 2014), described in comparison to $M$. setosa var. paludosa (Borges et al. 2014).

Most morphological features studied are qualitative, while others are quantitative features coded by relational proportions (e.g., "Leaves, medial rachilla, length relative to the rachis"). Even though we are not concerned with phylogentic analysis, features and their states were coded following suggestions by Sereno (2007) and scored in a matrix produced with Mesquite 2.75 (Maddison \& Maddison 2015). Morphological variation between specimens fitting Barneby's (1991) taxon concepts is expressed in the scoring of multiple states for a given character. Only features varying between taxa were retained for comparison (Matrix available on MorphoBank (<http://morphobank.
org/permalink/?P2334>)). Differentiation between traits and characters was based on the known variation of other taxa within $M$. ser. Setosae and species were delimited by the presence of at least one distinctive character.

\section{Source of data}

Morphological features utilized to evaluate taxa delimitation were obtained either from living plants observed in natural populations or from herbarium specimens, including types, held in $\mathrm{A}, \mathrm{ALCB}, \mathrm{B}, \mathrm{BHCB}, \mathrm{BM}, \mathrm{CEN}, \mathrm{CESJ}$, DIAM, ESA, F, G, HB, HBG, HRCB, HTO, HUEFS, HUFU, IAN, IBGE, K, LE, M, MG, MO, NY, OUPR, P, PAMG, R, RB, RFA, S, SP, SPF, UB, UEC, US, VIC, W (acronyms according to Thiers, continuously updated). The taxonomic treatment presents a list of selected specimens (at least three, or one per Brazilian state of occurrence) belonging to each taxon, but a full list of analyzed and identified specimens is also given. When necessary, a microscope with 10-63 $\times$ magnification was used to analyze the specimens.

Terminology follows Radford et al. (1976) and Harris \& Harris (2001), as well as Barneby \& Grimes (1996) for venation patterns; Weberling (1989) for inflorescence typology; and Barroso et al. (1999) for fruit morphology. Features specific to Mimosa follow Barneby (1991).

Conservation status assessment and mapping

Conservation status was assessed using the GeoCAT Tool (Bachman et al. 2011) browser based tool that performs rapid geospatial analysis to ease the process of Red Listing taxa. Developed to utilise spatially referenced primary occurrence data, the analysis focuses on two aspects of the geographic range of a taxon: the extent of occurrence (EOO) and Area of Occupancy (AOO). Analyses were run with the IUCN default cell width of $2 \mathrm{~km}^{2}$. Values of $\mathrm{AOO}$ and $\mathrm{EOO}$ are given for each species. When absent from sheet's label information, geographical coordinates were obtained with the Species Link geoLoc tool (CRIA 2015), or by locating the collection point on Google Maps (<http://maps.google.com $>$ ). Recurrent collection points were used only once, both for mapping and conservation status assessment. The distribution maps were produced with QGIS version 2.10.1 (QGIS Development Team 2015). 


\section{Results}

The concepts and methods applied here to the Mimosa setosa complex led us to propose the recognition of six distinct species (Tab. 1), four of which are new combinations of infraspecific taxa previously described (Barneby 1991; Bentham 1876). Also, two varieties described by Barneby (1991) are viewed as expressions of intraspecific morphological variation and were synonymized under other taxa.
Species limits are strongly associated with geographical distribution. Four taxa have a narrow and allopatric distribution. The remaining two are more broadly distributed and sometimes sympatric with at least some of the other taxa. Mimosa paludosa shows the largest area of occurrence and also the broadest phenotypic plasticity.

Below we present a taxonomic treatment for the species recognized here.

Taxonomic treatment

\section{Key to species}

1. Leaflet secondary veins as prominent as the primary veins; corolla lobes tomentose with filiform setae completely covering the surface (Chapada dos Veadeiros, Goiás State).... 1. Mimosa granitica

1'. Leaflet secondary veins less prominent than the primary veins; corolla lobes pubescent with a combination of trichomes, and/or filiform setae, and/or glandular setae that do not conceal the lobe surface (distributed throughout Tropical Brazil).....

2. Branches, petioles, and rachides charged with triangular aculei, which have a broad longitudinally fusiform base (distributed throughout Tropical Brazil) 3. Mimosa paludosa

2'. Branches, petioles and rachides lacking aculei, or rarely with conical aculei (restricted to Distrito Federal or to the states of Goiás, Minas Gerais and São Paulo)....

3. Filiform setae of branches antrorse, but not appressed; plane setae of calyx rim not laterally fused; corolla lobes lacking filiform setae; fruits partially breaking into articles (western Minas Gerais State) 2. Mimosa neonitens

3'. Filiform setae of branches patent or forwardly appressed; plane setae of calyx rim laterally fused; corolla lobes mostly bearing filiform setae (rarely wanting in Mimosa setosa); fruits craspedia (i.e. completely breaking into articles)..

4. Shrubs or subshrubs with humifuse or shortly ascending stems $0.1-1 \mathrm{~m}$ tall; indumentum of branches and leaves lacking glandular setae or almost so; ellipsoid racemes 19-24× $11-13 \mathrm{~mm}$ (Distrito Federal)..... 6. Mimosa urbica

4'. Erect shrubs $0.5-3 \mathrm{~m}$ tall; indumentum of branches clothed with glandular setae; globose racemes 9-13 × 9-12 mm (states of Goiás, Minas Gerais or São Paulo).....

5. Indumentum of branches composed of forwardly appressed filiform setae with a bulbous base; leaves 5-8-jugate; fruits lacking filiform setae, valves partially and irregularly breaking long after seed liberation (Diamantina Plateau, Espinhaço Range, Minas Gerais State)..... 4. Mimosa rupigena

5. Indumentum of branches composed of simple trichomes and patent filiform setae, which gradually taper from base to apex; leaves 13-16-jugate; fruits bearing filiform setae, valves breaking into regular articles at the point of seed liberation (states of Goiás, Minas Gerais and São Paulo). 5. Mimosa setosa

1. Mimosa granitica (Barneby) L.M. Borges, comb. \& stat. nov.

Basionym: Mimosa setosa subsp. granitica Barneby (1991: 358-359). Type: Brazil. Goiás: Chapada dos Veadeiros, $20 \mathrm{~km} \mathrm{~W}$ of Veadeiros, granitic mountain at $1000 \mathrm{~m}$ [elev.], 16 February 1966, fl., H.S. Irwin et al. 12944 (holotype: UB!; isotypes: G!, GH!, K!, LE!, NY!, P!, R!, US!).

Figs. 1-8
Virgate shrubs 1-2.5 m tall, apparently lacking a thickened underground system; branches thin, tortuous, unarmed or armed with slightly incurved to antrorse aculei ca. 1-4.2 mm long. Indumentum composed of simple trichomes, filiform setae with or without a bulbous base, and stipitate glandular setae with a clavate head (triple indumentum); branches, petiole, rachis, rachillas and peduncles varying from almost glabrous to pubescent or 

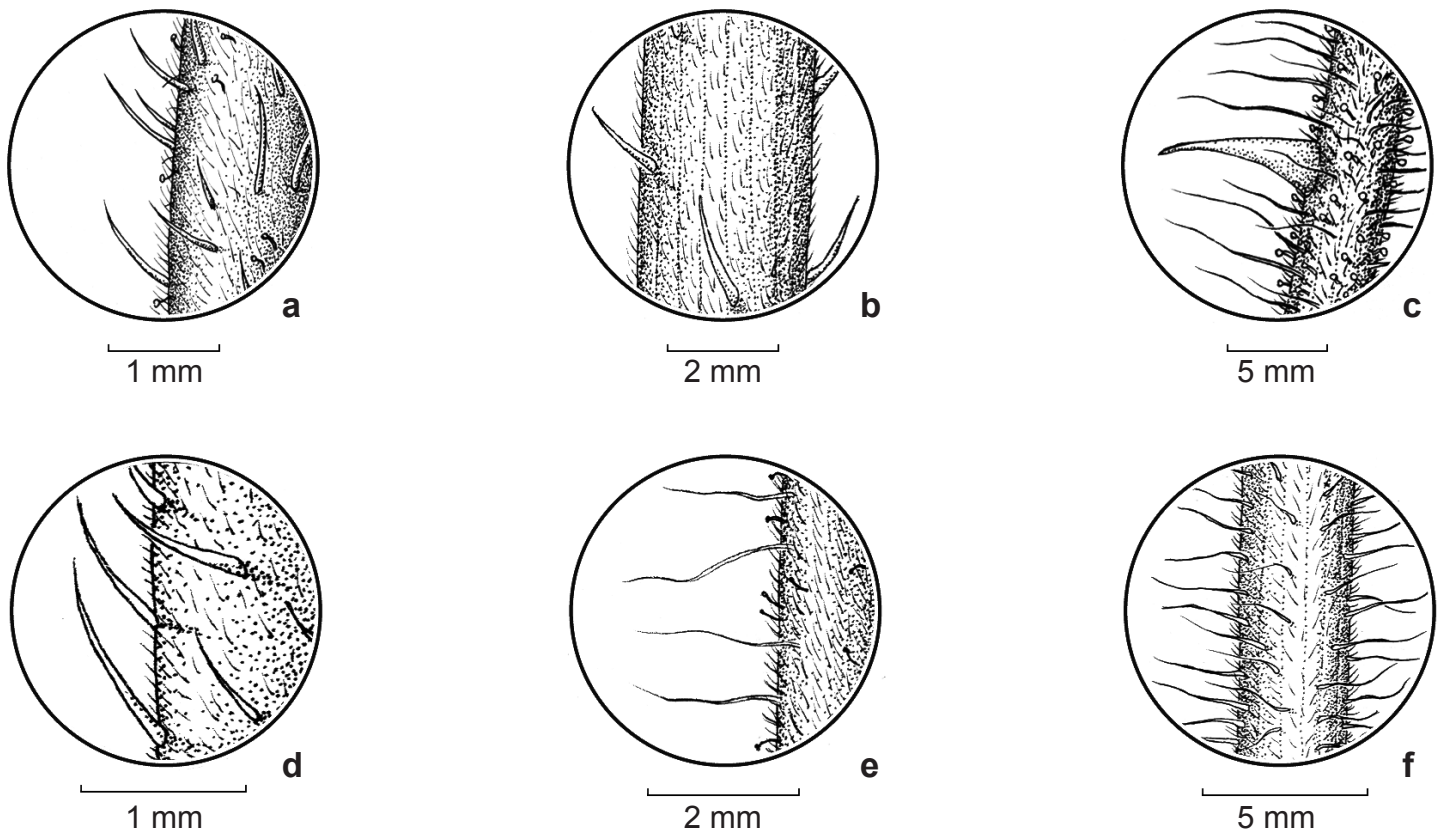

Figure 1 - Detail of the branch showing the indumentum - a. Mimosa granitica (Borges et al. 553); b. M. neonitens (Irwin et al. 25551); c. M. paludosa (Borges et al. 409); d. M. rupigena (Hatschbach \& R. Kummrow 49667); e. M. setosa (Borges et al. 1008); f. M. urbica (Borges et al. 515). Drawings by Laura Montserrat.

rarely tomentose with simple trichomes $0.2-0.4$ $\mathrm{mm}$ long, together with patent or antrorse (but not appressed filiform) setae $0.7-1.5 \mathrm{~mm}$ long, and patent glandular setae $0.2-0.8 \mathrm{~mm}$ long; branches whitish where the indumentum is abundant, shiny red-brown where it is sparse; stipules fully pubescent or only ciliate with the triple indumentum; leaflets ciliate with the triple indumentum, apex of abaxial surface of the latter sometimes pubescent with trichomes. Leaves 10-15-jugate, except for the usually 4-6-jugate leaves near, or at, the reproductive axis; stipules 5-7 $\times 1-1.4 \mathrm{~mm}$, narrowly triangular, plane to cymbiform (on reproductive axis), caducous; petioles 2-6.5(9) $\mathrm{mm}$ long, but up to $25 \mathrm{~mm}$ long on leaves near the reproductive axis, $1.4-2.1 \mathrm{~mm}$ diam., grooved on adaxial surface, the pulvinus $1.5-2.5 \mathrm{~mm}$ long; rachis $10.8-15.5(19.9) \mathrm{cm}$ long, 0.8-1.5 mm diam., also armed when the branches are aculeate, grooved on adaxial surface
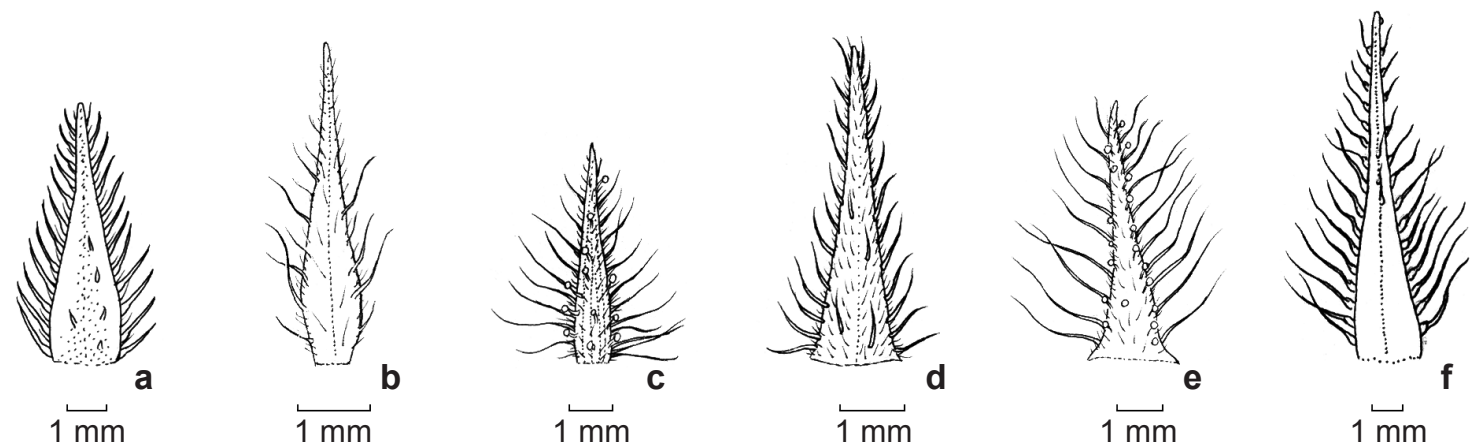

Figure 2 - Stipule - a. Mimosa granitica (Borges et al. 553); b. M. neonitens (Borges et al. 1027); c. M. paludosa (Borges et al. 409); d. M. rupigena (Hatschbach \& R. Kummrow 49667); e. M. setosa (Borges et al. 1008); f. M. urbica (Borges et al. 515). Drawings by Laura Montserrat. 
and with a laminar projection 1.1-1.7 mm long between each pinnae pair, terminal projection 2-5 mm long, linear or narrowly triangular; basal rachillas $12-32 \mathrm{~mm}$ long, medial rachillas $28-50$ $\mathrm{mm}$ long, distal rachillas 32-67(82) $\mathrm{mm}$ long, all $0.5-0.7 \mathrm{~mm}$ diam., $10-24 \mathrm{~mm}$ apart; leaflets $3.2-7 \times 1.3-2.4 \mathrm{~mm}$, in 10-17(21) pairs on basal rachillas, in $22-30$ pairs on medial rachillas, 14-31 pairs on distal rachillas, narrowly-oblong, inequilateral, 1.1-1.8 $\mathrm{mm}$ apart, apex rounded, rarely mucronulate, base oblique, subcordate, rounded-truncate, venation 5-6-palmate, primary and secondary veins equally prominent on abaxial surface; paraphyllidia $0.3-1 \times 0.1-0.3$ $\mathrm{mm}$, subulate. Inflorescences in pairs, distributed along terminal or axillary double-racemes, forming a bracteose paniculate synflorescence exserted from foliage. Racemes $12-14 \times 10-13$ $\mathrm{mm}$, almost spherical, axillary to leaves, not expanding after anthesis or fruit maturation; peduncles 14-34 mm long; floral bracts 4.9-5.2 $\times 1.2-1.4 \mathrm{~mm}$, narrowly or regularly spatulateacuminate, cymbiform, 1-nerved, tomentose with filiform setae $0.8-1.2 \mathrm{~mm}$ long and glandular setae $0.1-0.2 \mathrm{~mm}$ long, sometimes also with trichomes; flowers 4-merous, diplostemonous, basal flowers staminate only; pedicel $0.2-0.3$ mm long; calyx $0.4-0.5 \mathrm{~mm}$ long, cupulate, lobes ca. $0.1 \times 0.3-0.5 \mathrm{~mm}$, very shallowly triangular or absent, rim ciliate with filiform and plane setae $0.5-0.7 \mathrm{~mm}$ long, sometimes fused at base, and rarely also glandular setae ca. $0.3 \mathrm{~mm}$ long, tube glabrous; corolla 4.3-5.3 $\mathrm{mm}$ long, infundibuliform, tube glabrous, lobes

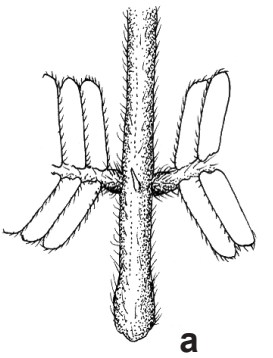

$5 \mathrm{~mm}$

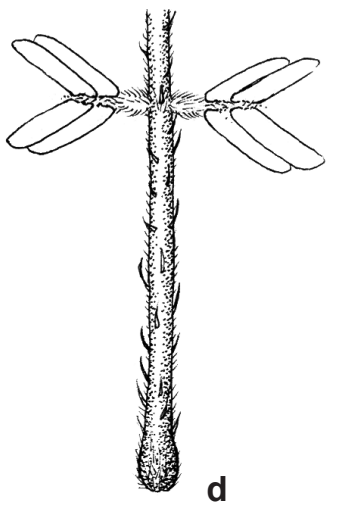

$5 \mathrm{~mm}$

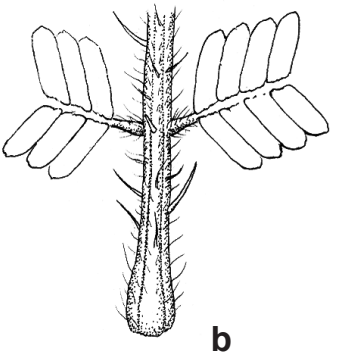

$5 \mathrm{~mm}$

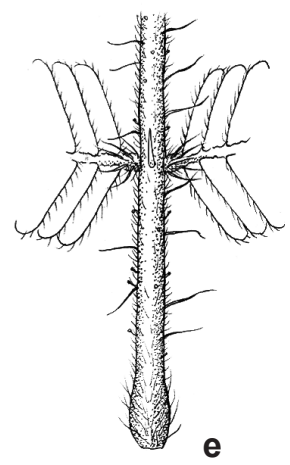

$5 \mathrm{~mm}$

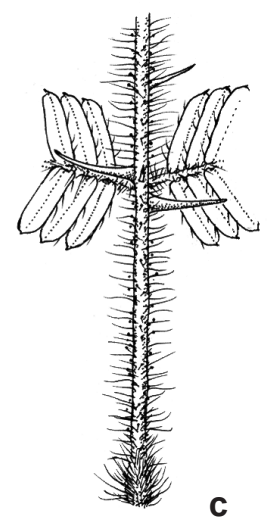

$\overleftarrow{5 \mathrm{~mm}}$

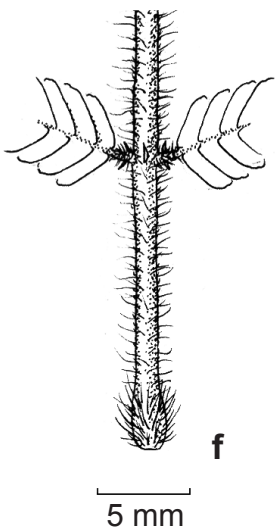

Figure 3 - Detail of the rachis with an interpinnal projection - a. Mimosa granitica (Borges et al. 553); b. M. neonitens (Irwin et al. 25551); c. M. paludosa (Borges et al. 409); d. M. rupigena (Hatschbach \& R. Kummrow 49667); e. M. setosa (Borges et al. 1008); f. M. urbica (Borges et al. 515). Drawings by Laura Montserrat. 

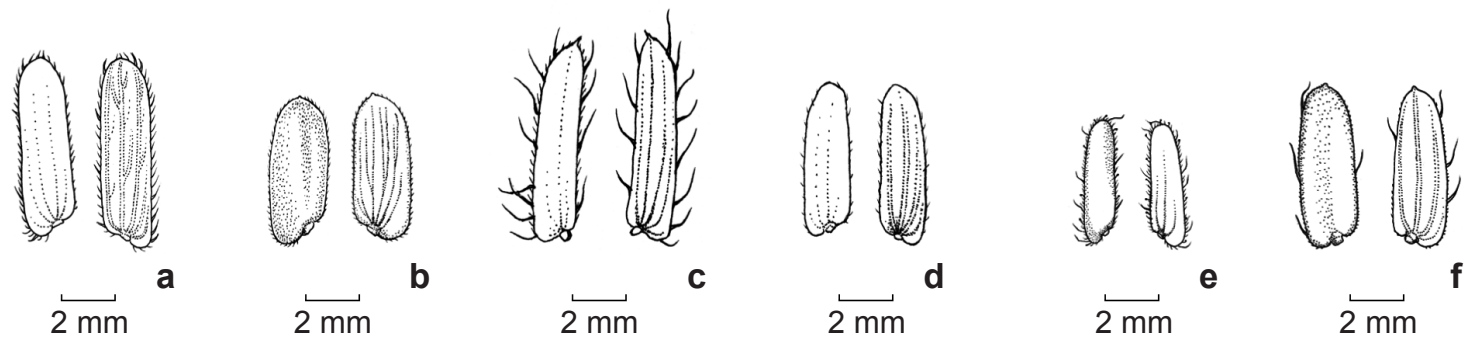

Figure 4 - Adaxial (to the left) and abaxial (to the right) surface of a leaflet - a. Mimosa granitica (Borges et al. 553); b. M. neonitens (Irwin et al. 25551); c. M. paludosa (Borges et al. 409); d. M. rupigena (Hatschbach \& R. Kummrow 49667); e. M. setosa (Borges et al. 1008); f. M. urbica (Borges et al. 515). Drawings by Laura Montserrat.

$0.9-1.5 \times 0.7-1.5 \mathrm{~mm}$, ovate, 1 -nerved, vein apex not prominent, tomentose with filiform setae $0.3-0.5 \mathrm{~mm}$ long, sometimes trichomes also present, indumentum concealing lobe surface; filaments $15-19 \mathrm{~mm}$ long, glabrous, fused $0.5-0.8 \mathrm{~mm}$ at base, pink; anthers $0.6-0.7$ $\times 0.7-0.8 \mathrm{~mm}$, glabrous; ovary $1.1-1.3 \times$ $0.5-0.8 \mathrm{~mm}$, compressed, elliptic, margins tomentose with filiform setae $0.5-0.6 \mathrm{~mm}$ long; stipe $0.2-0.3 \mathrm{~mm}$ long, glabrous; style $12-14$ $\mathrm{mm}$ long, glabrous; stigma porate, glabrous. Craspedium 40-70 $\times 9-12 \mathrm{~mm}$, narrowly oblong, papery, reddish-brown, apex obtuse to rounded, aristate, base cuneate, completely pubescent with trichomes, antrorse filiform setae $1-1.3 \mathrm{~mm}$ long and patent glandular setae $0.2-0.4 \mathrm{~mm}$ long; pedicel $6-13 \times 0.9-1.1 \mathrm{~mm}$; replum $0.8-1.3 \mathrm{~mm}$ wide; valves completely breaking only after seed liberation into 9-13 articles, central ones $2.5-4.3 \times 6.2-8.5 \mathrm{~mm}$, narrowly transversely oblong, veins prominent; 9-13 seeds per fruit $4.8-5 \times 3.8-4 \mathrm{~mm}$, ovate, lentiform, shiny brown, pleurogram present.

Mimosa granitica is distinguished from M. paludosa, the species to which it is most similar, by basal pinnae less than half the size of medial rachillas ( $v s$. equally long); leaflet's secondary veins equally prominent as primary veins ( $v s$. less than the primaries); corolla lobes with filiform setae concealing their whole surface ( vs. a different combination of elements of the triple indumentum that do not together conceal the surface); fruits with a stipe at least $5 \times$ longer than wide ( $v s$. less than $4 \times$ longer than wide or almost sessile).

The variation in indumentum is striking in Mimosa granitica, as already noted by Barneby (1991: 358-359), who even considered segregating a few specimens of this taxon as a different species during earlier studies of central Brazil collections. Specimens may be aculeate or not, densely villous to almost glabrous, and with filiform setae varying from thin to more robust and almost spiniform. This latter characteristic highlights the relationship that may exist between filiform setae and aculei in that they could be understood to be modified conditions of the same character. This supposed structural relationship needs to be evaluated with anatomical and developmental analyses. The
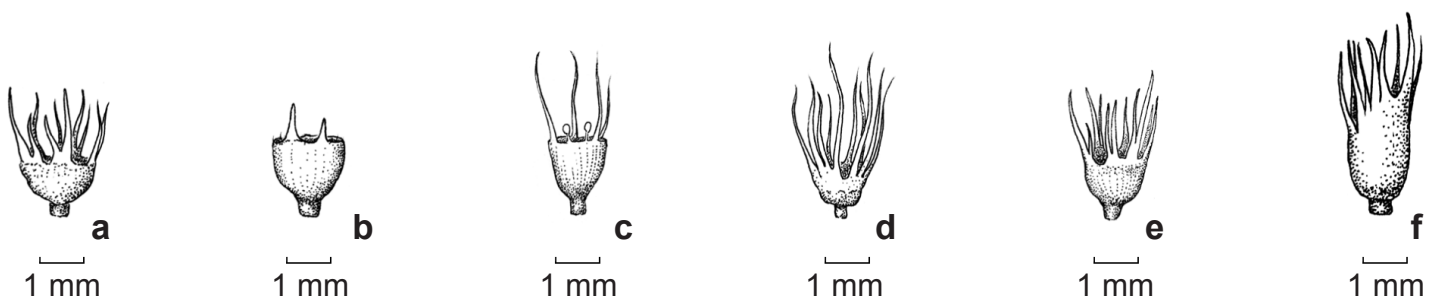

Figure 5 - Calyx - a. Mimosa granitica (Borges et al. 553); b. M. neonitens (Irwin et al. 25551); c. M. paludosa (Borges et al. 409); d. M. rupigena (Hatschbach \& R. Kummrow 49667); e. M. setosa (Borges et al. 1008); f. M. urbica (Borges et al. 515). Drawings by Laura Montserrat. 
specimen Irwin 33045, considered by Barneby (1991) as an aberration, is a remarkable example of the morphological variation of indumentum that can be found in M. granitica. Although not constant in $M$. granitica, the fusion between plane setae on the calyx rim, when present, may also be used to distinguish it from M. paludosa, which bears only free plane setae on the calyx rim.

Mimosa granitica is endemic to campos rupestres vegetation of the Chapada dos Veadeiros in northern Goiás at an elevation of 1000-1400 m (Fig. 8).

EN. GeoCAT analysis (EOO $101.633 \mathrm{~km}^{2}$; AOO $28 \mathrm{~km}^{2}$ ) indicates that Mimosa granitica is an endangered species. During observations in the field, it was possible to note that individuals are rare and sparse. Nonetheless, the few known collections of the species come from areas surrounding the Chapada dos Veadeiros National Park and it is very likely that the species also occurs within it.

Representative specimens examined: BRAZIL. GOIÁS: Alto Paraíso de Goiás, Chapada dos Veadeiros, Rodovia GO-118, Brasília - Monte Alegre de Goiás, ca. $7 \mathrm{~km}$ após Alto Paraíso, saída para o Hotel Fazenda

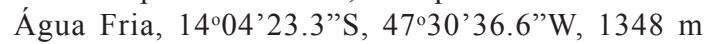
elev., 15 December 2010, fr., L.M. Borges et al. 511 (NY!, SPF!); Entroncamento entre a estrada GO-239 e a estrada para as Sete Lagoas, passando a leste do Morro da Baleia e pelo Peito de Moça, 1409'44.2"S, 47 37'47.5”W, $1146 \mathrm{~m}$ elev., 20 March 2012, fl. e fr., L.M. Borges et al. 553 (NY!, SPF!); Ca. $12 \mathrm{~km} \mathrm{NW}$ of Veadeiros, $1200 \mathrm{~m}$ elev., 19 October 1965, fr., H.S. Irwin et al. 9276 (NY!, SPF, UB!); Ca. $20 \mathrm{~km} \mathrm{~N}$ of Alto Paraíso, ca. $1250 \mathrm{~m}$ elev., 19 March 1971, fl., H.S. Irwin et al. 32231 (NY!, SPF!, UB!).
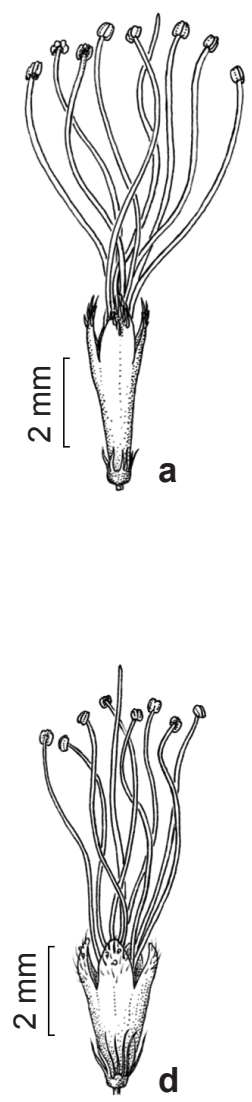
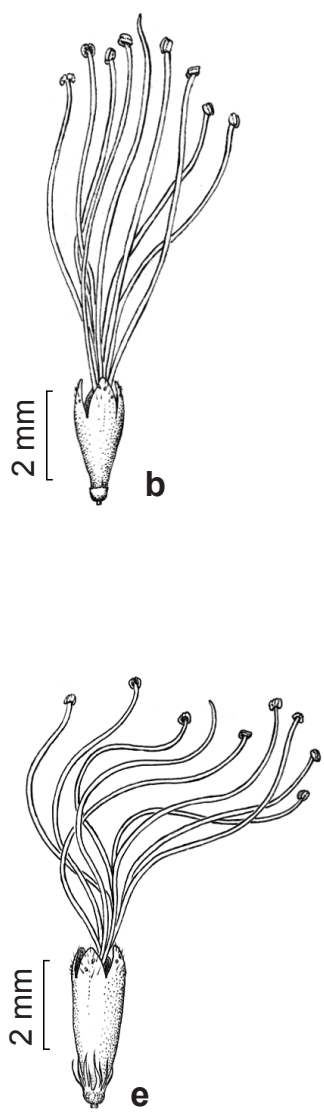
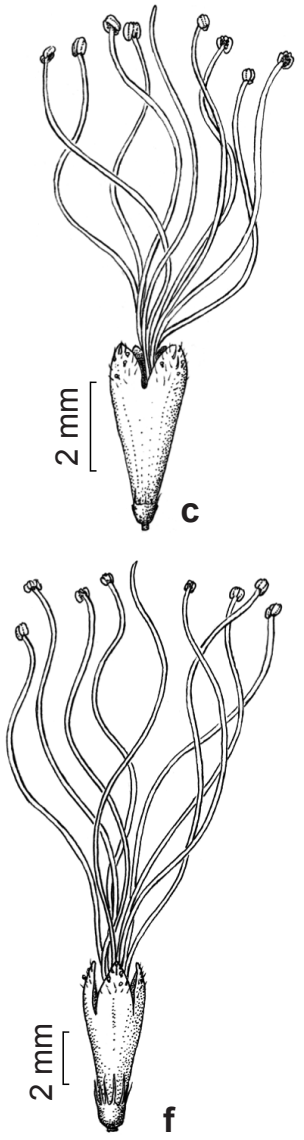

Figure 6 - Flower - a. Mimosa granitica (Borges et al. 553); b. M. neonitens (Irwin et al. 25551); c. M. paludosa (Borges et al. 409); d. M. rupigena (Hatschbach \& R. Kummrow 49667); e. M. setosa (Borges et al. 1008); f. M. urbica (Borges et al. 515). Drawings by Laura Montserrat. 


\section{Mimosa neonitens (Benth.) L.M. Borges, nom.} \& stat. nov.

Basionym: M. setosa var. nitens Bentham (1876: 387). Lectotype (designated by Barneby 1991: 357): Brazil. [probably Minas Gerais:] Habitat ad Arrado Veljo, fl., J.B.E. Pohl 664, (lectotype: W! [2 sheets]).

Figs. 1-6; 8; 9

Shrubs 1-2 m tall, sometimes prematurely flowering at only $50 \mathrm{~cm}$; branches thin, arising in fascicles from a thickened underground system, unarmed. Indumentum composed of simple trichomes, filiform setae with or without a bulbous base, and stipitate glandular setae with a clavate head (triple indumentum); branches, petiole, rachis, rachillas and peduncles pubescent with simple trichomes ca. $0.2 \mathrm{~mm}$ long, antrorse, but not appressed filiform setae $1.1-3 \mathrm{~mm}$ long and patent glandular setae $0.2-0.6 \mathrm{~mm}$ long; sometimes trichomes restricted to adaxial surface of leaf-axes and only filiform setae present on branches; stipules and leaflets ciliate with the triple indumentum; indumentum rarely present on abaxial face of stipules; leaflets sometimes lacking setae. Leaves 9-15-jugate, except for typically 3-4-jugate leaves
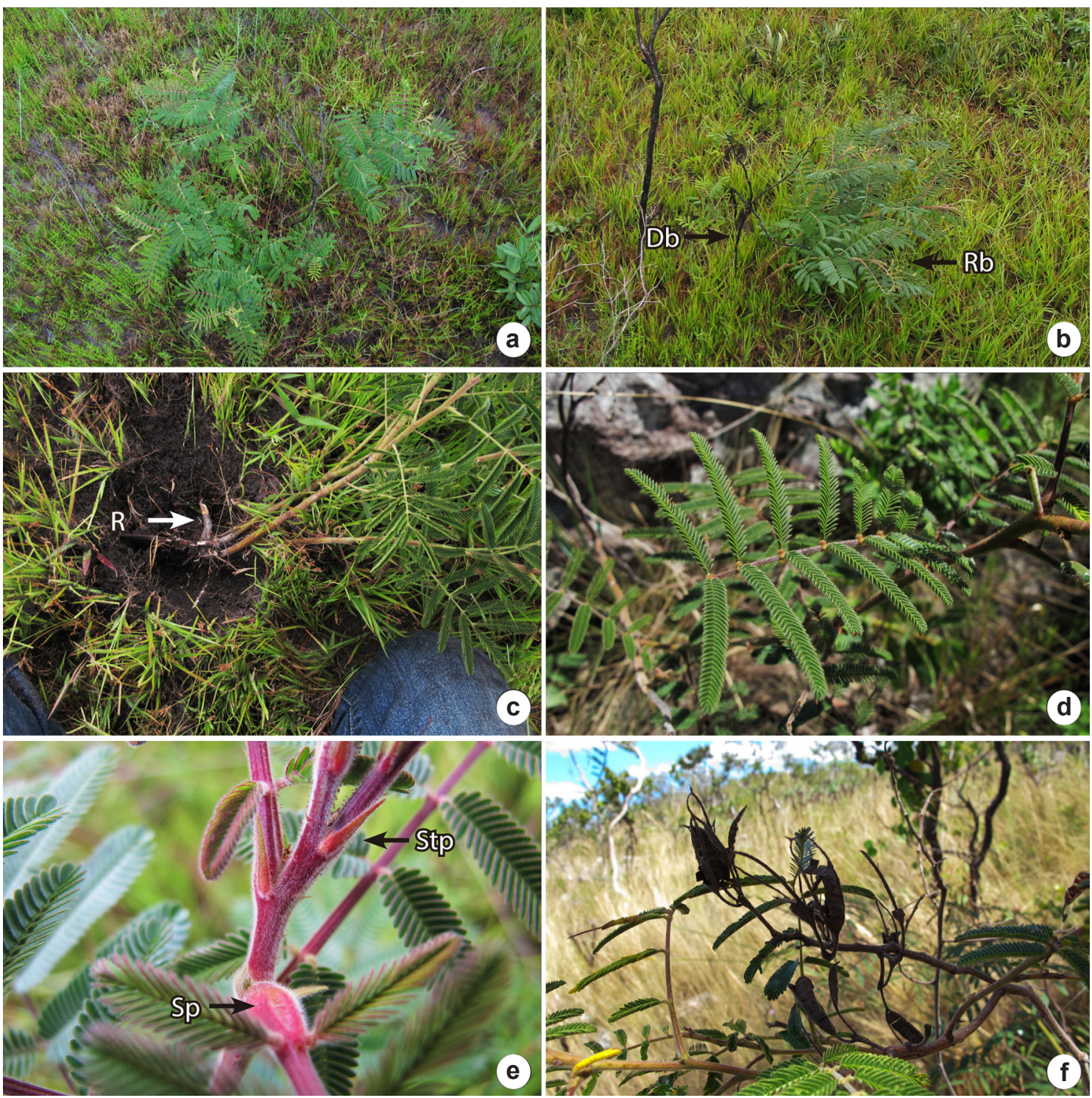

Figure 7 - Mimosa granitica - a. habit; $b$. habit showing a branch killed by fire $(\mathrm{Db})$ and a resprouted branch $(\mathrm{Rb})$; c. detail of the root system (R) showing lack of a xylopodium; d. leaf; e. detail of a leaf base showing one stipule (Stp) and the sulcate petiole (Sp); f. fruits. All photographs by L.M. Borges. 
at the reproductive axes; stipules $5.6-7 \mathrm{~mm} \times$ 0.9-1.7 mm, lanceolate-acuminate, cymbiform, caducous; petioles 9-15 mm long, 1.1-1.3 mm diam., grooved on adaxial surface, the pulvinus $1.5-2.5 \mathrm{~mm}$ long; rachis $7.5-15 \mathrm{~cm}$ long, $0.7-$ 1(1.4) $\mathrm{mm}$ diam., grooved on adaxial surface and with a laminar projection $0.7-1.8 \mathrm{~mm}$ long between each pinnae pair, terminal projection $2.7-3.2 \mathrm{~mm}$ long, linear; basal rachillas 20-29 mm long, medial rachillas 38-66 mm long, distal rachillas 42-64 $\mathrm{mm}$ long, all $0.4-0.5 \mathrm{~mm}$ diam., $8.5-17 \mathrm{~mm}$ apart; leaflets $3.5-6.5 \times 1.5-2.4 \mathrm{~mm}$, in 13-20 pairs on basal rachillas, in 20-37 pairs on medial rachillas, in 22-37 pairs on distal rachillas, narrowlyoblong, inequilateral, $1.2-2 \mathrm{~mm}$ apart, apex rounded, mucronulate, base oblique, subcordate, rounded-truncate, venation 4-5 palmate, primary veins slightly prominent only on abaxial surface; paraphyllidia $0.5-0.7 \times 0.2-0.3 \mathrm{~mm}$, subulate. Inflorescence a terminal or axillary exserted double-raceme of racemes, usually forming a frondose paniculate synflorescence exserted from foliage. Racemes 9-13 × 9-11 mm, spherical to slightly ellipsoid, 2-3-axillary to a suppressed leaf that expands after anthesis of its associated raceme and is fully expanded during fruit maturation; on prematurely flowering specimens, racemes may be axillary to a fully developed leaf; peduncles
15-42 mm long; floral bracts 3-5 × 0.9-1.2 $\mathrm{mm}$, narrowly acuminate-spatulate, cymbiform, 1-nerved, pubescent with trichomes, filiform setae $0.5-0.9 \mathrm{~mm}$ long and glandular setae $0.2-0.4 \mathrm{~mm}$ long; flowers 4-merous, diplostemonous, basal flowers only staminate; pedicel ca. $0.1 \mathrm{~mm}$ long; calyx $0.4-0.5 \mathrm{~mm}$ long, cupulate, lobes ca. 0.1 $\times 0.6 \mathrm{~mm}$, very shallowly triangular, rim ciliate with trichomes, plane, but not fused, filiform setae $0.5-0.9 \mathrm{~mm}$ long (sometimes restricted only to less than half of the rim), and rarely also glandular setae ca. $0.3 \mathrm{~mm}$ long, tube glabrous; corolla 4-4.5 $\mathrm{mm}$ long, infundibuliform, tube glabrous, lobes $0.8-1.2 \times 1.2-1.3 \mathrm{~mm}$, ovate, 1 -nerved, vein apex not prominent, pubescent with glandular setae ca. $0.1-0.3 \mathrm{~mm}$ long (rarely absent), sometimes simple trichomes also present, indumentum not concealing lobes surface; filaments 19-22 mm long, glabrous, fused ca. $0.5 \mathrm{~mm}$ at base, pink; anthers $0.7-0.8 \times$ $0.7-0.8 \mathrm{~mm}$, glabrous; ovary $1.2-1.4 \times 0.5-0.7$ $\mathrm{mm}$, compressed, elliptic, margins tomentose with filiform setae 1-1.4 $\mathrm{mm}$ long and glandular setae $0.2-0.4 \mathrm{~mm}$ long, stipe $0.3-0.4 \mathrm{~mm}$ long, glabrous; style 20-20.5 mm long, glabrous; stigma porate, glabrous. Craspedium 26-47 × 9-11 mm, narrowly oblong, papery, greyish-brown, apex obtuse to rounded, aristate, base cuneate, completely pubescent with trichomes, margins sometimes

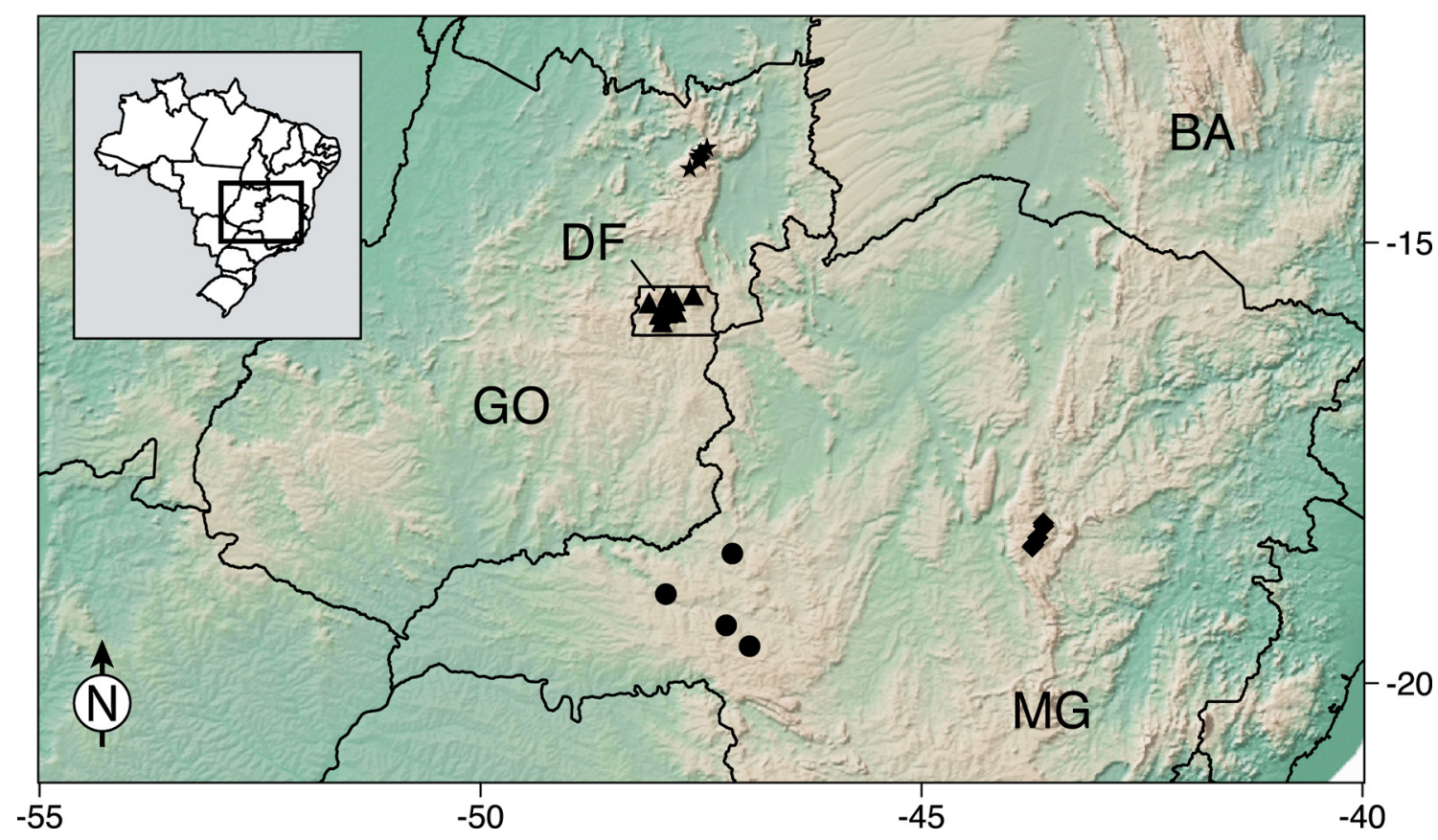

Figure 8 - Distribution of Mimosa granitica $(\star)$; M. neonitens $(\bullet)$; M. rupigena $(\diamond)$; and M. urbica $(\mathbf{\Delta})$. (BA = Bahia state; $\mathrm{DF}=$ Distrito Federal; $\mathrm{GO}=$ Goiás state; $\mathrm{MG}=$ Minas Gerais state). 

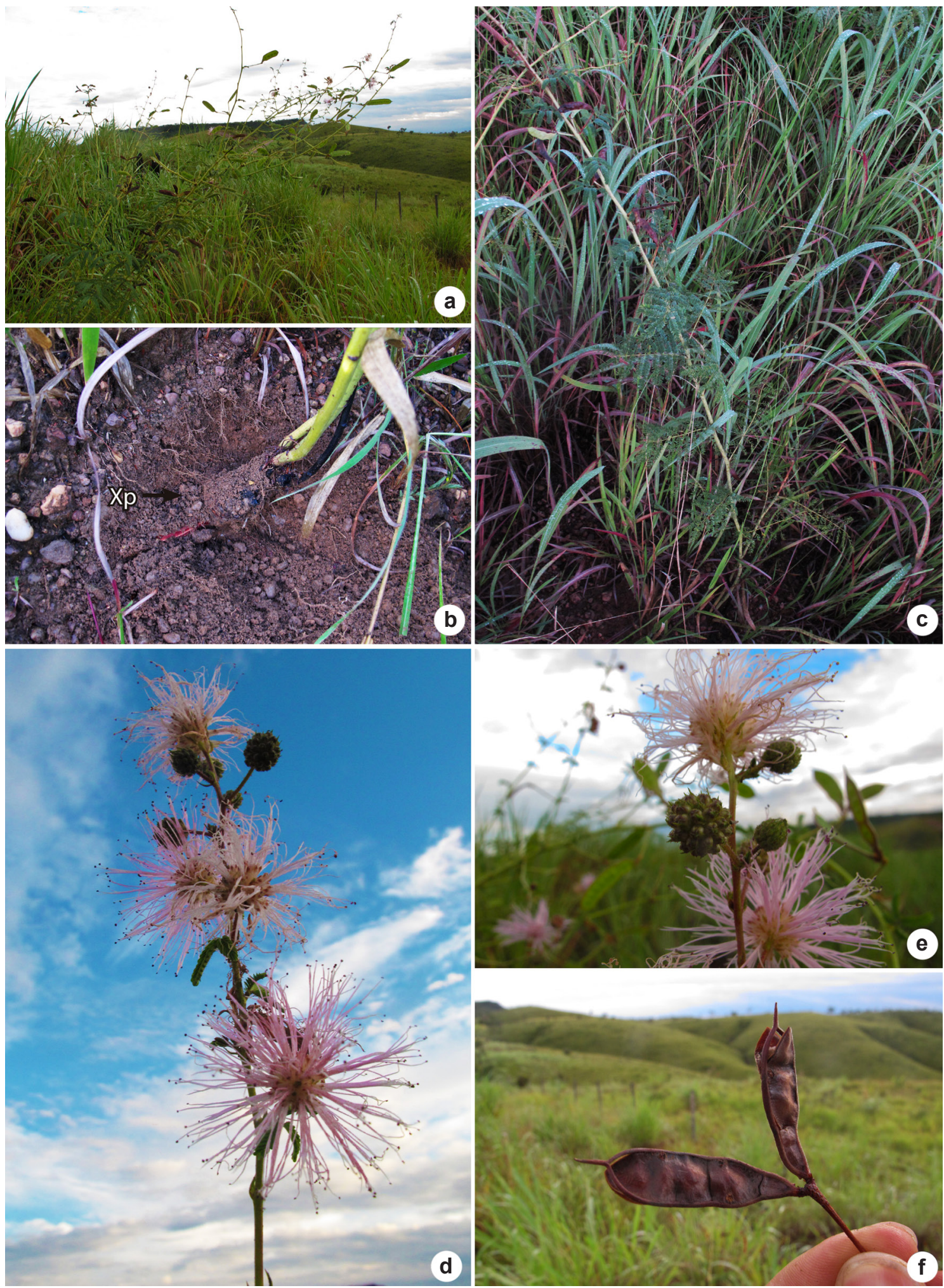

Figure 9 - Mimosa neonitens - a. branch; b. detail of the root system showing the developed xylopodium (Xp); c. virgate stem with leaves; d. synflorescence axis with racemes subtended by heterochronic leaves; e. detail of the globose racemes; f. fruits. All photographs by L.M. Borges. 
ciliate with filiform setae $1.2-1.8 \mathrm{~mm}$ long, as well as glandular setae $0.4-1.2 \mathrm{~mm}$ long; pedicel ca. 2-4 × 1-1.5 mm; replum 1.3-1.5 mm wide; valves completely or partially breaking at point of seed liberation into 4-9 articles, central articles 4-4.7 $\times 6.5-8 \mathrm{~mm}$, transversely oblong; 4-9 seeds per fruit 4.7-5.5 × 3.1-3.5 mm, ovate, lentiform, shiny dark brown, pleurogram present.

Mimosa neonitens stands out as one of the most distinct taxa in the M. setosa complex, having particular dissimilarities to each of the other species, but differing from all by branches with antrorse, but not appressed, setae (vs. patent, or forwardly appressed). It differs from M. paludosa by the absence of aculei and by the valves partially articulated ( $v s$. completely breaking into articles). It may be readily distinguished from $M$. setosa by the presence of a thickened underground system ( $v S$. absence); presence of shallowly triangular calyx lobes (vs. absence); and fruits partially articulated (vs. completely articulated). Mimosa neonitens strongly resembles $M$. maguirei Barneby (1991), which is endemic to the Southern Espinhaço Range but can be readily distinguished by the glaucous glabrous stems and branches.

Since the epithet "nitens" was previously occupied at species level by Mimosa nitens Bentham (1842), a new name is necessary when treating $M$. setosa var. nitens Bentham (1876) at specific rank.

Barneby (1991) considered the calyx of Mimosa neonitens (as $M$. setosa var. nitens) as "essentially" the same as that of $M$. paludosa, probably in reference to the absence of fusion between the plane projections on the calyx rim in both taxa. In M. neonitens, however, the projections may be restricted to less than half of the rim circunference. Fruits of $M$. neonitens are nitid, somewhat papery, lack both filiform and glandular setae on their valves, and only partially break into articles. Consequently, those fruit features stand out as peculiar amongst the taxa related to $M$. setosa, all showing at least one type of setae on valves and usually completely articulated.

Mimosa neonitens also shares similarities with M. myrioglandulosa Dutra \& Garcia (2012), and the areas of occurrence for both species are relatively close, even though not coincident. Mimosa myrioglandulosa differs from $M$. neonitens by the lack of filiform setae on stems, its sessile (i.e. not stipitate) glandular setae and, primarily, by its un-jointed craspedial fruit, which was erroneously described as a "sacelo" by Dutra \& Garcia (2012).
Nonetheless, the fruits of $M$. neonitens break irregularly, and the degree of splitting of the valves can vary in a number of Mimosa taxa (e.g., Simon et al., 2010). The affinity between $M$. neonitens and M. myrioglandulosa should be further investigated.

Barneby (1991) indicated that the type was probably collected in the state of Goiás, interpreting the unknown locality "Arrado Velho" as a corrupted form of "Corgo Vermelho". This is very unlikely, since neither name shares any similarity in Portuguese, i.e., Old Plow and Red Stream, respectively. All modern collections of Mimosa neonitens have been made, however, in campos rupestres in the state of Minas Gerais, some near the state's northern border with Goiás, where Pohl probably collected the type specimen when passing by the area of Paracatu in 1818 or 1820 (R. Mello-Silva, personal communication).

The name "neonitens" refers to the new (neo) rank herein adopted for the taxon named by Bentham (1876), alluding to a bright (nitens) feature of the plant, possibly the leaflets.

Mimosa neonitens is found in campo rupestre, campo in red clay, cerrado and cerrado rupestre of western Minas Gerais State at elevations between 850 and $1050 \mathrm{~m}$ (Fig. 8). One record describing the plant habitat as woods (Arruda 206) is certainly inaccurate. It is worth noting that Mimosa neonitens has been repeatedly collected in the campos rupestres of Morro das Pedras, in Coromandel, Minas Gerais (Borges 1027; Irwin 25551), which is also the site of the only three collections known for $M$. lithoreas Barneby (1991). This highlights the importance of exploring these areas botanically before their particular flora becomes extremely endangered by the ongoing expansion of agricultural land, which already surrounds them.

EN. Mimosa neonitens is indicated as being either vulnerable, based on Extent of Occurrence $\left(5165.969 \mathrm{~km}^{2}\right)$, or as endangered, according to Area of Occupancy $\left(16 \mathrm{~km}^{2}\right)$, as obtained by a GeoCAT analysis. However, we have chosen to consider $M$. neonitens as endangered, essentially because one of the points used in the analysis refers to the municipality of Araxá, Minas Gerais State, and not to the exact point of collection. This approximation probably overestimaes the size of the polygon used by the GeoCAT tool to calculate EOO values. Our decision is reinforced by anthropogenic pressure currently placed on the species habitat (see above).

Selected specimens examined: BRAZIL. MINAS GERAIS: Araguari, $40 \mathrm{~km}$ NO da cidade de Araguari, 
25 May 1963, fl., G.M. Magalhães 19266 (HB!, NY!); Coromandel, Rodovia MG-188, Coromandel-Patrocínio, $11 \mathrm{~km}$ do trevo de saída em Coromandel, 18³1'44.2”S, 4708'42.7'W, 28 March 2013, fl. e fr., L.M. Borges et al. 1027 (SPF!, NY!, RB!); Perdizes, Estação Ambiental Galheiro, Macega, 7 March 2003, fl. e fr., E.H. Amorim et al. 697 (HUFU!).

3. Mimosa paludosa Bentham(1842: 400). Lectotype (designated by Barneby 1991: 354): Brazil. Marshy [ground] near Barra do Jardim [7 $7^{\circ} 35^{\prime} \mathrm{S}, 39^{\circ} 15^{\prime} \mathrm{W}$ in southern Ceará (Barneby 1991)], December 1838, G. Gardner 1942 (lectotype: K!; isolectotypes: BM!, E, F!, G!, K!, NY!, P!, W!).

Mimosa setosa subsp. paludosa (Benth.) Barneby (1991: 354). Mimosa setosa var. paludosa [autonym generated by $M$. setosa var. metadenotricha].

Mimosa setosa var. metadenotricha Barneby (1991: 354), syn. nov. Type: Brazil. Distrito Federal: 3 km s. of Sobradinho, 1 May 1966, fl., H.S. Irwin et al. 15523 (holotype: UB!; isotypes: G!, GH!, K!, LE!, MBM, NY!, P!, R!, S!, US!).

Figs. 1-6; 10; 11

Shrubs to treelets $1-3 \mathrm{~m}$, lacking a thickened underground system; branches, petioles, rachides, and sometimes margins of fruits armed with straight to inclined aculei $2-9 \times 1-10 \mathrm{~mm}$ with a broad and longitudinally fusiform base, sometimes antrorse and smaller. Indumentum composed of simple trichomes, filiform setae with or without a bulbous base, and stipitate glandular setae with a clavate head (triple indumentum); branches, stipules, petiole, rachis, rachillas and peduncles hirsute with simple trichomes $0.2-0.4 \mathrm{~mm}$ long, patent filiform setae $1-8.5 \mathrm{~mm}$ long, and patent glandular setae $0.4-2.5$ $\mathrm{mm}$ long (the smaller setae present on leaflets and the larger ones on branches); leaflets ciliate with the triple indumentum. Leaves 4-11-jugate; stipules $10-12.5 \mathrm{~mm} \times 0.6-1 \mathrm{~mm}$, narrowly linear triangular to lanceolate-acuminate, plane, caducous; petioles 15-30 mm long, 1.3-1.8 mm diam., grooved on adaxial surface, the pulvinus $1.5-2.5 \mathrm{~mm}$ long; rachis $7-9.2 \mathrm{~cm}$ long, $0.8-1 \mathrm{~mm}$ diam., grooved on adaxial surface and with a spiculate or glandular projection $0.6-1.3 \mathrm{~mm}$ long randomly present between each pinnae pair, usually concealed by the indumentum, terminal projection 7-7.5 $\mathrm{mm}$ long; basal rachillas $30-35 \mathrm{~mm}$ long, medial rachillas 38-52 mm long, distal rachillas 48-64 mm long, all $0.3-0.5 \mathrm{~mm}$ diam., $9-17 \mathrm{~mm}$ apart, distance decreasing acroscopically; leaflets $4.5-7 \times 1-1.5$ $\mathrm{mm}, 24-25$ pairs on basal rachillas, 25-30 pairs on medial rachillas, 26-37 pairs on distal rachillas, narrowly-oblong, inequilateral, 1.3-1.6 mm apart, apex acute, mucronulate, base oblique, subcordate, rounded-truncate, venation 5-palmate, primary veins slightly prominent on abaxial surface; paraphyllidia $0.4-0.5 \times 0.1-0.2 \mathrm{~mm}$, subulate. Inflorescences in fascicles of 2-3 racemes, distributed along terminal bracteose double-racemes exserted from foliage, axillary leaves partially developed during anthesis, fully expanding during fruit maturation. Racemes 9-11 × 9-10 mm, spherical; peduncles $22-30 \mathrm{~mm}$ long; floral bracts $4.2-5.5 \times 0.8-1.2$ $\mathrm{mm}$, narrowly spatulate-acuminate to spatulateacuminate, cymbiform, tomentose with trichomes (sometimes absent), filiform setae 1-2 mm long, and glandular setae 0.3-0.5 mm long; flowers 4-merous, diplostemonous, basal flowers only staminate; pedicel ca. $0.2 \mathrm{~mm}$ long, glabrous; calyx $0.4-0.7$ $\mathrm{mm}$ long, cupulate, lobes lacking or ca. $0.1 \times 0.5$ $\mathrm{mm}$, very shallowly triangular, rim ciliate with a random combination of trichomes, filiform setae $0.5-0.6 \mathrm{~mm}$ long, plane setae not fused at base ca. $0.5 \mathrm{~mm}$ long, and glandular setae $0.1-0.3 \mathrm{~mm}$ long, but never glabrous, tube usually glabrous, sometimes with filiform and glandular setae at the apex; corolla 4.5-4.8 mm long, infundibuliform, tube glabrous, lobes $0.9-1.6 \times 1-1.4 \mathrm{~mm}$, ovate, 1-nerved, vein apex prominent, pubescent with a random combination of trichomes, filiform setae $0.3-0.5 \mathrm{~mm}$ long, and glandular setae ca. $0.1 \mathrm{~mm}$ long, rarely completely glabrous, indumentum not concealing lobes surface; filaments 10-14 mm long, glabrous, fused $0.3-0.5 \mathrm{~mm}$ at base, pink; anthers $0.5-0.6 \times 0.6-0.7 \mathrm{~mm}$, glabrous; ovary $1.1-2.9 \times$ 0.4-1.3 mm, compressed, elliptic, tomentose with filiform setae $0.8-1.3 \mathrm{~mm}$ long, and glandular setae $0.1-0.4 \mathrm{~mm}$ long, stipe $0.2-0.3 \mathrm{~mm}$ long, glabrous; style $7-13 \mathrm{~mm}$ long, glabrous; stigma porate, glabrous. Craspedium 53-82 × 9-10 mm, narrowly oblong, papery to chartaceous, brown, apex acute, aristate, base cuneate, completely pubescent with trichomes, antrorse filiform setae 1.3-1.7 mm long and patent glandular setae $0.5-1.5 \mathrm{~mm}$ long; pedicel $1.5-3 \times 1-1.3 \mathrm{~mm}$; replum 1.1-1.4 mm wide; valves completely breaking at the point of seed liberation into 7-10 articles, central ones $6-6.5 \times 7.5-8 \mathrm{~mm}$, transversely widely oblong, veins not prominent; 7-10 seeds per fruit $4.5-5 \times 4.1-4.5 \mathrm{~mm}$, widely ovate, lentiform, shiny brown, pleurogram present.

Most morphological features used to distinguish other species in the Mimosa setosa complex are variable within Mimosa paludosa, posing a problem for its circumscription. However, the presence of straight to slightly inclined aculei is constant on individuals of the species, a feature 
that is shared with $M$. granitica and, rarely, with $M$. setosa, but these species may, in turn, be differentiated by the prominence of the leaflet secondary veins of $M$. granitica and the absence of prickles on petioles and rachis, as well as calyces with their plane projections laterally fused, of $M$. setosa. The absence of fusion between such structures on the calyx of $M$. paludosa is shared with $M$. granitica and $M$. neonitens, but the latter is distinguished by its partially articulated fruits and presence of a thickened underground system (see also characterization section of each species for further details).

Although a few features are constant in Mimosa paludosa, most of its characters are prone to variation. As Barneby (1991) noted, the indumentum is particularly variable in density, length and composition. Even though the triple indumentum tends to be constantly present in branches, corollas may have almost all possible combinations of trichomes with filiform setae and glandular setae. The length of filiform setae
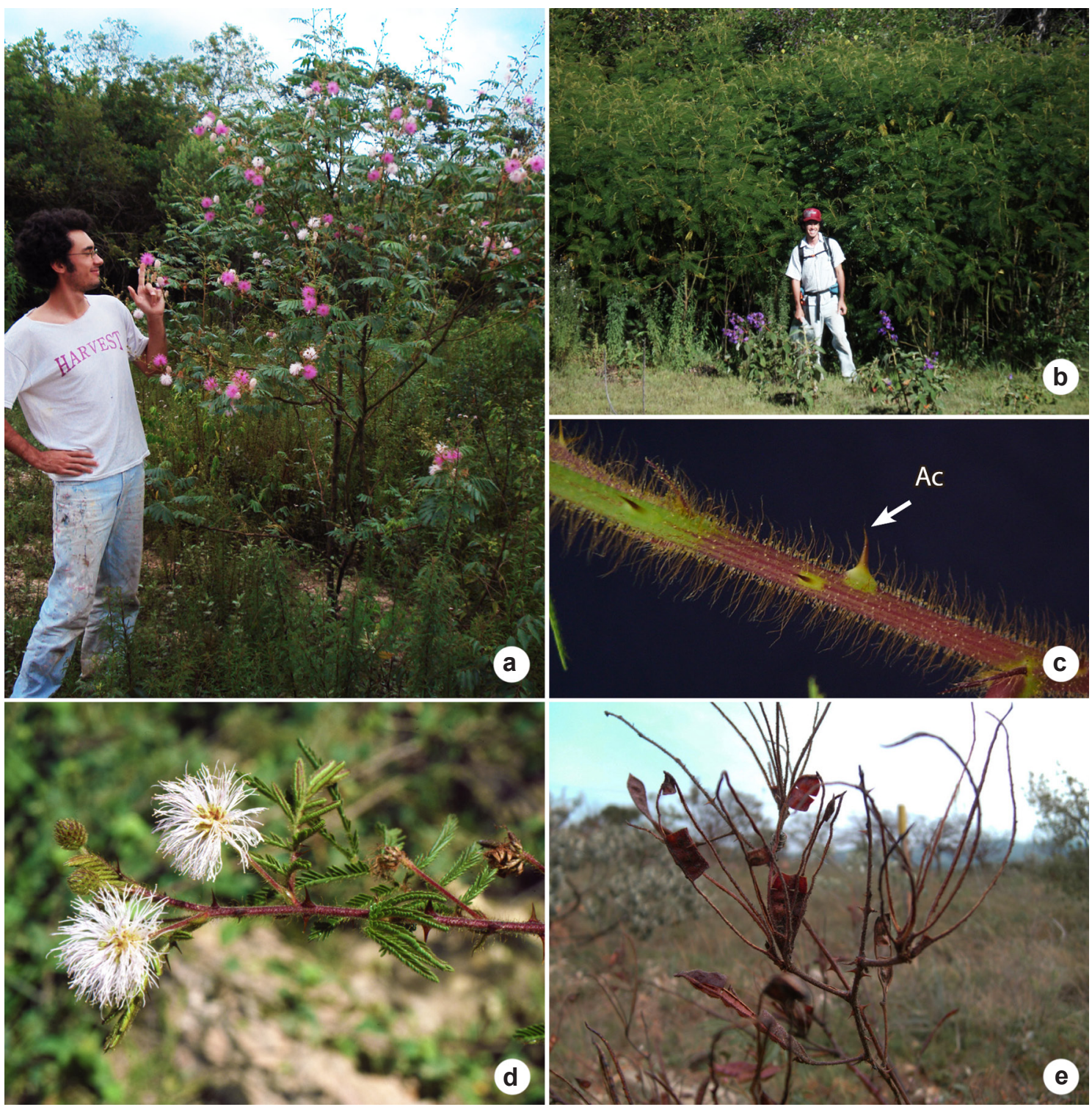

Figure 10-Mimosa paludosa - a. habit; b. densely clustered individuals; c. detail of a branch evidencing the aculeus (Ac); d. synflorescence; e. fruits after breakage of the valves. (Photos: a-b. by J.G. Rando; c. by M.F. Simon; d. by G.P. Lewis; e. by L.M. Borges). 
on floral bracts is also a notable variable, but, at the same time, misleading, since it does not occur in a pattern that would allow segregation of potential taxa.

In the mountains of Chapada Diamantina, of the state of Bahia, and Grão Mogol, in Minas Gerais State, filiform setae are randomly present on specimens that also have thicker and broader fruits, and that appear to differ from typical M. paludosa specimens (e.g., Harley et al. 25771, Ganev 1940, Mello-Silva 1445, Barreto CFCR 12097). However, no character state clearly supports recognition of populations from those areas as distinct species. They appear to fit the same scenario as discussed below for M. setosa var. metadenotricha. We stress that such populations, which also show allometric variation on leaves and racemes, should be further investigated.

The inclusion of Mimosa setosa var. metadenotricha in synonymy under M. paludosa reflects the recognition of the latter as a morphologically plastic species. Segregation of these taxa as different entities could serve as a basis to name many geographical variants of the species and promote description of taxa that are only visually dissimilar. Moreover,
Barneby (1991) incorrectly considered M. setosa var. metadenotricha as ecologically distinct by its occurrence in dry environments. However, the type of M. setosa var. metadenotricha, in fact, was not collected in such places, but in a "creek margin", the typical environment of occurrence of M. paludosa. There is evidence that older specimens that can be identified as M. setosa var. metadenotricha (e.g., Glaziou 21052) were probably also collected near streams or marshes.

On the other hand, Mimosa occidentalis var. novo-galiciana Barneby is excluded from the list of synonyms of $M$. paludosa, based on the absence of filiform setae on stipules, and leaflet margin ( $v s$. present); secondary veins of leaflets as prominent as the primary veins ( $v s$. less prominent as the primary veins); elliptic-rhombic floral bracts ( $v s$. spatulateacuminate); and ovate calyx lobes (vs. absent or very shallowly triangular). In fact, $M$. occidentalis var. novo-galiciana appears to be a taxon of Mimosa ser. Neptunioideae Barneby (1991), to which it was assigned by Barneby (1991). Although we do agree that this taxon should not be treated as a variety of M. occidentalis, it was mistakenly equated with $M$. paludosa by Grether (2000).

The specimen Irwin 15499 (NY) presents most morphological characteristics of Mimosa

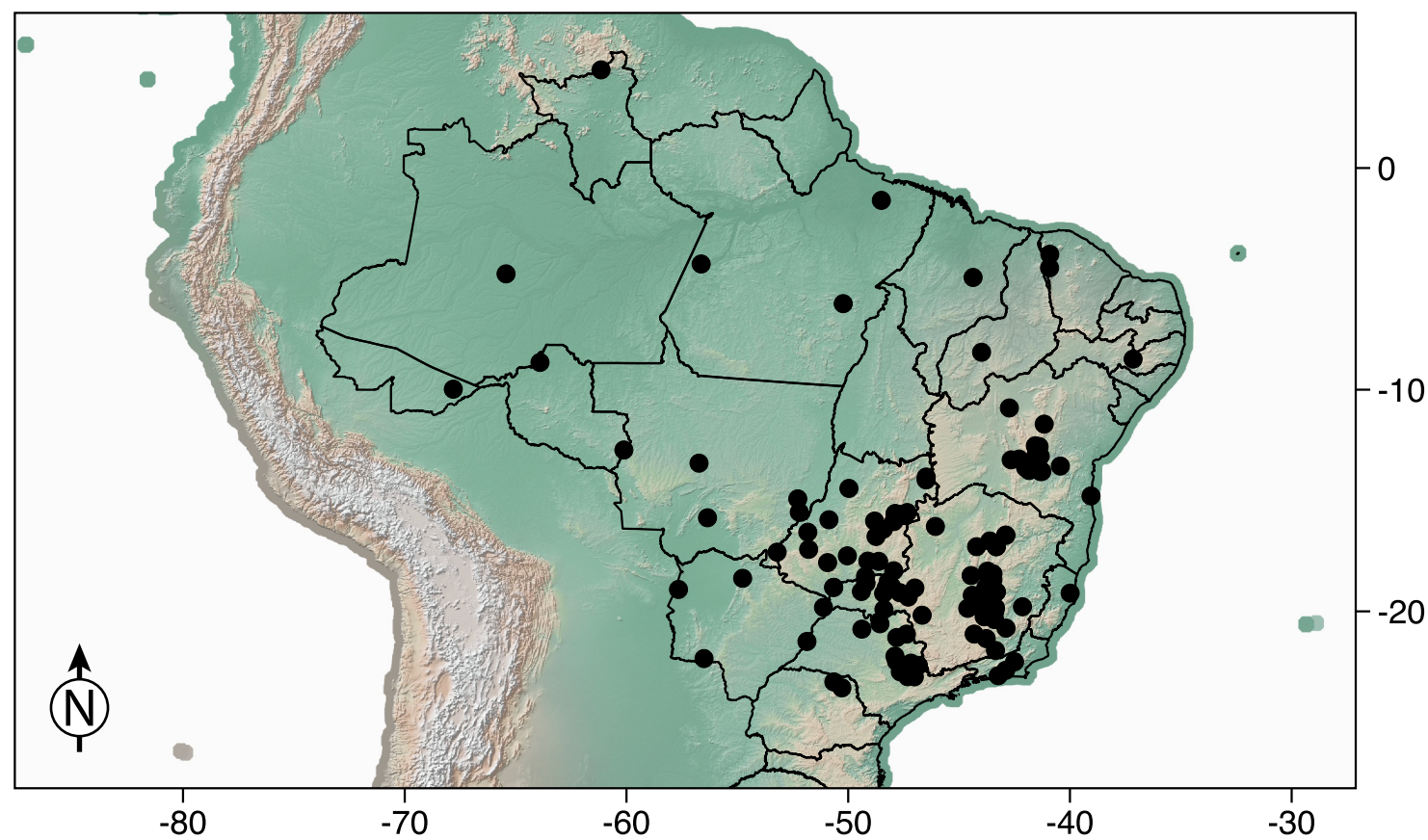

Figure 11 - Distribution of Mimosa paludosa in Brazil, with one record to Bolivia, near the border with Brazil (see selected specimens for details). 
paludosa, but corollas with lobes concealed by antrorse filiform setae. This feature is present in $M$. granitica and other species belonging to $M$. ser. Pachycarpae. We were not able to ascertain whether this is a new taxon or another example of morphological plasticity within M. paludosa. This is further complicated by the lack of fruits on this collection. Additional investigations are needed in the source region of the Paranã River, where this puzzling plant was collected.

Species recently described (M. perplicata and $M$. serpensetosa; Borges et al. 2014) share morphological characters in common with Mimosa paludosa, particularly indumentum and armature of branches, but differ from it either by habit, or floral features, as well as particular leaf morphology.

Mimosa paludosa is known to have a variable number of chromosomes (Dahmer et al. 2010), which are probably related to the wide geographical distribution and morphological plasticity of this species.

In natural environments, Mimosa paludosa occurs in riverine forest or areas with sandy, or sandy to clay-like, marshy areas of cerrado, campos rupestres, and rainforest in Brazil, stretching to the border with Paraguay, but probably also beyond it. It has the broadest distribution range of species in the M. setosa complex, and it is one of the most common South American species of the genus Mimosa. Mimosa paludosa is also an opportunistic weed able to grow in different types of disturbed areas, such as pastures and roadsides, but apparently always in sites prone to have humid soils more constantly.

LC. Considering values of $\mathrm{EOO}(6,792,705.658$ $\left.\mathrm{km}^{2}\right)$ and AOO $\left(560 \mathrm{~km}^{2}\right)$ obtained with the GeoCAT tool, the conservation status of Mimosa paludosa is assessed as of least concern or vulnerable, respectively. Although the polygon obtained for EOO includes regions without many documented sites of occurrence for the species, particularly northern and far west Brazil (values of EOO change if points in those areas are excluded, but not the inferred status), we chose to consider it of least concern based on its broad distribution and high frequency, as well its ability to grow in disturbed areas.

Selected specimens examined: BRAZIL. ACRE: Rio Branco, Rodovia BR-364, 30 April 1995, L.C.L. Meneses Filho 11 (NY!). AMAZONAS: Presidente Figueiredo, na beira da BR-174, próxima ao município, 15 December 2011, fl., M.F. Santos \& M.T.C. Watanabe 771 (NY!, SPF!). BAHIA: Rio de Contas, Pico das

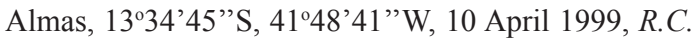

Forzza 1162 (NY!, RB!). CEARÁ: São Benedito, Inhuçu, Serra da Ibiapaba, 4²'55'S, 40'51'54"W, 24 July 1971, A.G. Fernandes (NY 443300!). DISTRITO FEDERAL: Brasília, Cachoeira do Colorado, próximo à fábrica de asfalto, $15^{\circ} 35^{\prime} \mathrm{S}, 4^{\circ} 53^{\prime} \mathrm{W}$, M.F. Simon 61 (UB!). ESPÍRITO SANTO: Linhares, Reserva Natural da Companhia Vale do Rio Doce, estrada Peroba Amarela, Km 1,2, 7 July 2006, L.M. Borges et al. 119 (CVRD). GOIÁS: Caiapônia, Córrego d'Anta, ca. $40 \mathrm{~km} \mathrm{~S}$. of Caiapônia, road to Jataí, Serra do Caiapó, [17¹5'00's, 5148'00”'W,] 900 m elev., 26 June 1966, H.S. Irwin 17728 (LE!, NY!, UB!). MARANHÃO: Entrada para Ouro Preto, 2 October 1997, S.M. de Faria 1377 (RB!). MATO GROSSO: Nossa Senhora do Livramento, about 5 $\mathrm{km}$ southeast of Pirizal village along the trail to Coqueiro Lake, $16^{\circ} 14^{\prime} \mathrm{S}, 56^{\circ} 15^{\prime} \mathrm{W}, 120 \mathrm{~m}$ elev., 15 July 1993, $M$. Schessl 3384 (NY!). MATO GROSSO DO SUL: Rio Verde, Sete Quedas, 8 August 1997, G. Hatschbach 66574 (ESA!, HBG!, MBM!, NY!). MINAS GERAIS: Diamantina, Estrada Mendanha-Inhaí, margens do Rio Jequitinhonha, 1802'40"S, 43'32'48'W, elev. ca. 700 m, 6 February 2009, fl., L.M. Borges 390 (NY!, SPF!). PARÁ: Belém, Ramal de entrada na area da APEG, próximo à estrada do CEASA, 4 January 2000, M.R. Cordeiro 4809 (IAN!, K!). PARANÁ: Cornélio Procópio, Arredores de Cornélio Procópio, 29 August 1996, F. Chagas e Silva 1952 (HUEFS!, K!). PERNAMBUCO: Buíque, Vale do Catimbau, Trilha da Cachoeira, 24 January 2006, A. Bocage 1079 (HUEFS!). PIAUÍ: $G$. Gardner 1942 (BM!, G!, NY!, W!). SÃO PAULO: Altinópolis, 6 km Altinópolis-Batatais, 9 May 1981, J.A. Winder 193/A (K!). RIO DE JANEIRO: Cachoeiras de Macau, 6 distrito, Fazendas consorciadas - Fazenda Sertão, 22²7'25'S, 4249'64'W, 120 m elev., 2 October 2000, F.B. Pereira 0638 (RB!). RONDÔNIA: Porto Velho, Vila de Nova Califórnia, BR-364, Ramal da Mendes Júnior, Rio Azul, Área indígena de Caxarari, 27 October 1997, L.C.B. Lobato 2253 (MG!). PARAGUAY. AMAMBAY: Bella Vista, Rio Aquidaban, camino de Ruta 5 a Bella Vista, 23 June 1977, A. Krapovickas 32594 (CTES, K!, NY!).

4. Mimosa rupigena (Barneby) L.M. Borges, comb. \& stat. nov.

Basionym: M. setosa var. rupigena Barneby (1991: 357-358). Type: Brazil. Minas Gerais: Gouveia, 6 September 1971, fl. e fr., G. Hatschbach 27302 (holotype: NY!; isotypes: HBG!, MBM).

Figs. 1-6; 8

Shrubs $0.5-2 \mathrm{~m}$ tall; unarmed. Indumentum composed of simple trichomes, filiform setae with bulbous base, and stipitate glandular setae with clavate head; branches, petiole, rachis, rachillas and peduncles pubescent with filiform setae 1.2-2 $\mathrm{mm}$ long; petiole, rachis, rachillas also with a few sparse glandular setae ca. $0.2 \mathrm{~mm}$ long; rachillas and peduncles also with trichomes ca. $0.1 \mathrm{~mm}$ 
long; the filiform setae, which are forwardly appressed on branches, become antrorse, but not appressed on peduncles and synflorescence axes; leaflets completely pubescent with trichomes and ciliate with filiform setae, rarely bearing glandular setae. Leaves 5-8-jugate; stipules 3.5-7 $\mathrm{mm} \times$ $0.3-0.5 \mathrm{~mm}$, linear, plane, ciliate with trichomes and filiform setae, caducous; petioles $31-42 \mathrm{~mm}$ long, 0.9-1.2 mm diam., grooved on adaxial surface, pulvinus 1.5-2.5 mm long; rachis (5)7-9 $\mathrm{cm}$ long, $0.8-1 \mathrm{~mm}$ diam., grooved on adaxial surface and with a spiculate projection $0.8-1.7$ $\mathrm{mm}$ long between each pinnae pair, terminal projection 2-3.5 $\mathrm{mm}$ long, linear; basal rachillas $30-45 \mathrm{~mm}$ long, medial rachillas $50-60 \mathrm{~mm}$ long, distal rachillas 60-74 $\mathrm{mm}$ long, all 0.4-0.5 $\mathrm{mm}$ diam., $10-17 \mathrm{~mm}$ apart; leaflets 3-6.3 $\times$ 1.3-1.7 mm, (15-)29-30 pairs on basal rachillas, 20-41 pairs on medial rachillas, 33-40 pairs on distal rachillas, narrowly-oblong, inequilateral, 1.5-2 mm apart, apex rounded, mucronulate, base oblique, subcordate, rounded-truncate, venation 4-5-palmate, sometimes veins slightly prominent only on abaxial surface; paraphyllidia $0.5-0.7 \times$ $0.2-0.3 \mathrm{~mm}$, subulate. Inflorescences arranged in fascicles of 1-2, distributed along double-racemes, organized in a terminal, exserted from foliage, bracteose, and paniculate synflorescence. Racemes $8-13 \times 8.5-12 \mathrm{~mm}$, spherical, development of axillar leaves not observed during or after fruit maturation; peduncles 12-24 mm long; floral bracts $5.9-6.8 \times 0.8-1 \mathrm{~mm}$, narrowly acuminate-spatulate, cymbiform, 1-nerved, hirsute with filiform setae 1.8-2.5 mm long and sometimes a few glandular setae ca. $0.2 \mathrm{~mm}$ long; flowers 4-merous, diplostemonous, basal flowers only staminate; pedicel $0.1-0.2 \mathrm{~mm}$ long; calyx $0.2-0.5 \mathrm{~mm}$ long, cupulate, lobes absent, rim ciliate with plane setae 1.6-2.7 mm long, irregularly fused at base, tube glabrous; corolla 3.5-5 mm long, infundibuliform, tube glabrous, lobes $1-1.6 \times 0.9-1.2 \mathrm{~mm}$, ovate, 1 -nerved, vein apex not prominent, pubescent with trichomes ca. $0.1 \mathrm{~mm}$ long, filiform setae $0.9-1.4 \mathrm{~mm}$ long and glandular setae ca. $0.2 \mathrm{~mm}$ long, indumentum not concealing lobe surface; filaments 11-14 mm long, glabrous, fused ca. 0.2 $\mathrm{mm}$ at base, pink; anthers ca. $0.5 \times 0.5-0.6 \mathrm{~mm}$, glabrous; ovary 1-1.3 $\times 0.5-0.7 \mathrm{~mm}$, compressed, elliptic, margins tomentose with filiform setae ca. 1 $\mathrm{mm}$ longand glandular setae $0.1-0.2 \mathrm{~mm}$ long, stipe $0.2-0.3 \mathrm{~mm}$ long, glabrous; style $13-14 \mathrm{~mm}$ long, glabrous; stigma porate, glabrous. Craspedium 28-43 ×9-12 mm, narrowly oblong, papery, dark- brown, apex obtuse to rounded, obliquely aristate, base cuneate, completely pubescent with trichomes (sometimes lacking on old fruits) and hirsute with filiform setae 2-2.5 mm long and glandular setae $0.4-1.8 \mathrm{~mm}$ long, the latter more abundant; pedicel $0.8-2.3 \times 1.3-1.4 \mathrm{~mm}$; replum $0.8-1.3 \mathrm{~mm}$ wide; valves partially and irregularly breaking long after seed liberation; seeds not seen.

Mimosa rupigena is the only species within the $M$. setosa complex to present forwardly appressed cauline setae. Particularly, it differs from $M$. paludosa and $M$. setosa by the absence of glandular setae on branches (vs. presence) and by leaves not developing on synflorescence axes after maturation of the fruits ( $v s$. developing). Additionally, it lacks prickles, which are always present in M. paludosa. It may also be distinguished from $M$. neonitens by its bracteose synflorescence ( $v s$. frondose), by the presence of trichomes on the leaflet surface ( $v s$. absence) and by plane projections along the circumference of the calyx rim.

The fruit indumentum is mainly composed of thick glandular setae, which may lose their heads with time, thus seeming to be filiform setae. The latter are less frequent, but easily observed on young fruits, whose very slim tips allow clear distinction from the capitate glandular ones. It is still unknown if $M$. rupigena has a thickened underground system.

Mimosa rupigena is restricted to campos rupestres and cerrados with rock outcrops and rocky soils from the Diamantina plateau, which is located within the Espinhaço Range in the state of Minas Gerais, between 1000-1400 m in elevation.

EN. Assignment of conservation status is discordant between EOO $\left(37.611 \mathrm{~km}^{2}\right)$ and AOO $\left(20 \mathrm{~km}^{2}\right)$, as estimated by GeoCAT analysis for Mimosa rupigena. The former assessed the species as Critically Endangered and the latter as Endangered. M. rupigena is, indeed, a rare species seldom sampled in a relatively well collected region. Nevertheless, since two of the five points used on the analysis are placed within the Biribiri State Park, we choose to categorize M. rupigena as endangered.

Representative specimens examined: BRAZIL. MINAS GERAIS: Datas, Rodovia Diamantina-Gouveia (BR-367), 18²0'54'S, 4340'60[?]'W, ca. $1350 \mathrm{~m}$ elev., 5 February 2009, fr., L.M. Borges et al. 370 (SPF!, NY!); Diamantina, Biribiri, Alto da Sentinela, 646170/7988977, 1100 m elev., 16 September 2004, fl., C.V. Mendonça et al. 1141 (DIAM!); Gouveia, Córrego do Tigre, 14 September 1985, fl. e fr., G. Hatschbach \& R. Kummrow 49667 (K!, MBM, NY!, SPF!). 
5. Mimosa setosa Bentham (1842: 404). Lectotype (designated by Barneby 1991: 355) Brazil. Goiás: ad Rio São Marcos [locality in Bentham (1876) (Barneby 1991)], December 1818, J.B.E. Pohl 846 [=d. 1409] (lectotype: $\mathrm{K}$ (herb. Benth.)!; isotypes: F!, K (herb. Hooker)!, NY!, W!).

Mimosa formosana Taubert (1896: 433). Lectotype (designated by Borges \& Pirani 2014: 216): Brazil. Goiás: [Formosa], "prope Formosa", September 1894, fl., E. Ule 2827 (HBG! [also annotated as "No 4"; "Chapadões bei Formosa"]); synonymized by Barneby (1991).

Mimosa setosa subsp. setosa var. pseudomelas Barneby (1991: 356-357), syn. nov. Type: Brazil. São Paulo: ad Vila de Batatais, fl., fr., A.F. Regnell III/510 [Ser. III $n^{\circ}$ 510] (holotype: K!; isotypes: $\mathrm{S} !)$.

Figs. 1-6; 12; 13

Shrubs 0.5-3 m tall; thickened underground system absent; generally unarmed, but occasionally with patent aculei ca. $1.5 \mathrm{~mm}$ long and $0.3-0.4$ $\mathrm{mm}$ wide at the circular base, usually on the older portions of branches (hence rarely represented on exsiccatae) and sometimes occurring on apical portions and leaf rachis. Indumentum composed of simple trichomes, filiform setae with bulbous base, and stipitate glandular setae with a clavate head (triple indumentum); branches, petioles, rachides, rachillas and peduncles pubescent with simple trichomes $0.3-0.4 \mathrm{~mm}$ long, filiform setae 1.4-3.3 mm long, and glandular setae $0.5-1 \mathrm{~mm}$ long; leaflets ciliate with the triple indumentum and sometimes pubescent with trichomes on both surfaces. Leaves 13-16-jugate; stipules 3.5-7 × 0.3-0.5 mm, linear, plane, ciliate with trichomes and filiform setae, caducous; petioles $24-27 \mathrm{~mm}$ long, 2-2.7 mm diam., grooved on adaxial surface, the pulvinus $1.5-2.5 \mathrm{~mm}$ long; rachis $17-25.8 \mathrm{~cm}$ long, 1.2-1.6 mm diam., grooved on adaxial surface and with a laminar projection 1.1-2 mm long between each pinnae pair, terminal projection 5.5-6 $\mathrm{mm}$ long, linear; basal rachillas 36-41 mm long, medial rachillas $43-58 \mathrm{~mm}$ long, distal rachillas 40-50 mm long, all 0.4-0.5 mm diam., 7-15 mm apart; leaflets $2.8-4.8 \times 0.8-1.2 \mathrm{~mm}, 31-41$ pairs on basal rachillas, 31-50 pairs on medial rachillas, 35-40 pairs on distal rachillas, narrowly-oblong, inequilateral, 1.2-1.4 mm apart, apex rounded, base oblique, subcordate, rounded-truncate, venation at least 3-palmate, veins not prominent; paraphyllidia $0.4-0.7 \times$ ca. $0.2 \mathrm{~mm}$, subulate. Inflorescences arranged in fascicles of 1-2 distributed along double-racemes, organized in a terminal, usually exserted from foliage, bracteose, and paniculate synflorescence; sometimes inflorescences may be nested in the foliage, instead of exserted in a secondary synflorescence. Racemes 9-13 × 9-12 $\mathrm{mm}$, spherical, development of axillary leaves not observed during or after fruit maturation; peduncles 12-24 mm long; floral bracts 5.9-6.8 $\times 0.8-1$ $\mathrm{mm}$, narrowly acuminate-spatulate, cymbiform, 1-nerved, hirsute with filiform setae $1.8-2.5 \mathrm{~mm}$ long; flowers 4-merous, diplostemonous, basal flowers only staminate; pedicel $0.1-0.2 \mathrm{~mm}$ long; calyx $0.2-0.5 \mathrm{~mm}$ long, cupulate, lobes absent, rim ciliate with plane setae $1.6-2.7 \mathrm{~mm}$ long, fused irregularly at base, tube glabrous; corolla 3.5-5 mm long, infundibuliform, tube glabrous, lobes 1-1.6 × 0.9-1.2 mm, ovate, 1-nerved, vein apex not prominent, pubescent with trichomes ca. $0.1 \mathrm{~mm}$ long, filiform setae $0.9-1.4 \mathrm{~mm}$ long, and glandular setae ca. $0.2 \mathrm{~mm}$ long, indumentum not concealing lobe surface; filaments $11-14 \mathrm{~mm}$ long, glabrous, fused ca. $0.2 \mathrm{~mm}$ at base, pink; anthers ca. $0.5 \times 0.5-0.6 \mathrm{~mm}$, glabrous; ovary $1-1.3 \times 0.5-0.7 \mathrm{~mm}$, compressed, elliptic, margins tomentose with filiform setae ca. $1 \mathrm{~mm}$ long and glandular setae $0.1-0.2 \mathrm{~mm}$ long; stipe $0.2-0.3 \mathrm{~mm}$ long, glabrous; style 13-14 mm long, glabrous; stigma porate, glabrous. Craspedium 28-43 $\times$ 9-12 mm, narrowly oblong, papery, dark-brown, apex obtuse to rounded, obliquely aristate, base cuneate, completely pubescent with trichomes (sometimes lacking on old fruits) and hirsute with filiform setae $2-2.5 \mathrm{~mm}$ long and glandular setae 0.4-1.8 mm long, the latter more abundant; pedicel 0.8-2.3 × 1.3-1.4 mm; replum 0.8-1.3 mm wide; valves breaking into regular articles at point of seed liberation; seeds not seen.

Mimosa setosa stands out as a species distinct from $M$. paludosa by the absence of aculei on the petiole and rachis (vs. presence), and plane setae of the calyx rim laterally fused, and from M. urbica mainly for being an erect shrub (vs. a trailing subshrub).

Very rarely, Mimosa setosa may present a few aculei scattered on branches (e.g., Borges 1008; Heringer 12242). However, these are somewhat conical and smaller than those occurring in $M$. paludosa, which are usually triangular, with a broad longitudinally fusiform base.

Barneby (1991) noted the striking affinity among Mimosa setosa, M. melanocarpa and $M$. setosa var. pseudomelas and also pointed out that Bentham named specimens of $M$. setosa var. pseudomelas initially as $M$. setosa and later as $M$. melanocarpa (Barneby 1991). M. setosa and $M$. 
melanocarpa differ by several characters, notably the stipitate fruits and the abundant presence of filiform setae on pedicels of the calyx of $M$. melanocarpa (referred by Barneby [1991] as being located on the calyx tube). All the differences $M$. setosa var. pseudomelas possesses from $M$. melanocarpa are shared with $M$. setosa, except for the absence of filiform setae on fruits. Hence, $M$. setosa var. pseudomelas is transitional between $M$. setosa var. setosa and M. melanocarpa, as thought by Barneby (1991), only when the presence of stipitate fruits is taken into account. Nonetheless, this character is variable, and fruits of $M$. setosa var. pseudomelas may be stipitate or sessile, even on the same specimen (e.g., Handro 738). Barneby (1991) also used lack of interpinnal projections ("interpinnal spicules") to distinguish $M$. setosa var. pseudomelas. However, study of specimens that could be ascribed to this variety and the isotype at US reveals the presence of such projections, which are fragile and prone to detach from the rachis upon manipulation, leaving an almost imperceptible scar. This could explain their overall absence in specimens analyzed by Barneby and his misuse of that feature as informative. Based on the above, M. setosa var. pseudomelas is herein synonymized under M. setosa, in agreement with Bentham's original finding.

Mimosa setosa occurs between 700 and 1200 $\mathrm{m}$ in elevation in lateritic soils of cerrados in the Distrito Federal and the states of Goiás and São Paulo, central and southeastern Brazil, respectively.
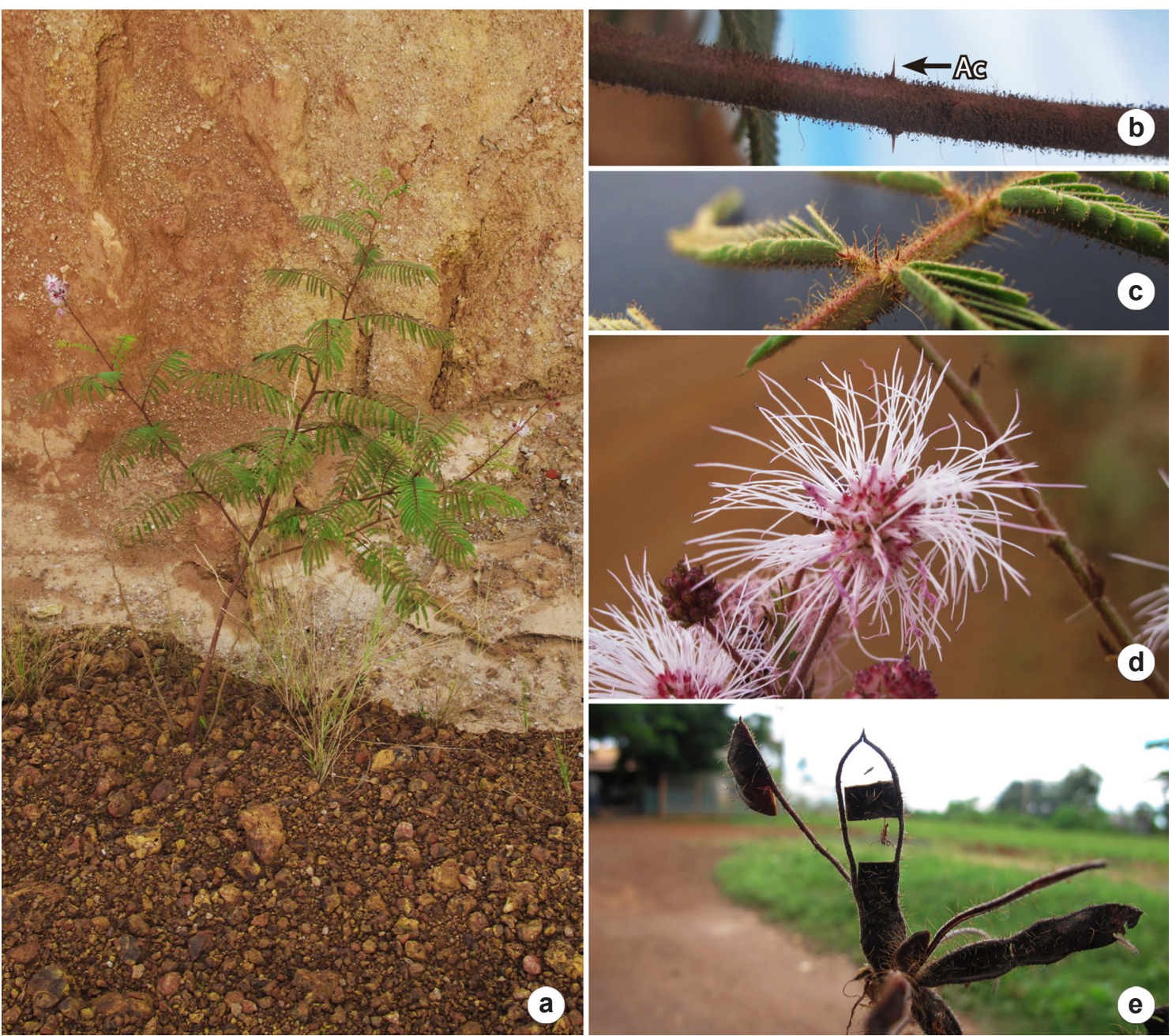

Figure 12 - Mimosa setosa - a. habit; b. branch with aculei (Ac) seldom found in the species; c. detail of a leaf showing the interpinnal projection; d. raceme; e. fruits. All photographs by L.M. Borges. 
LC. According to GeoCaT tool analysis, Mimosa setosa is considered of least concern by EOO value $\left(184,437.204 \mathrm{~km}^{2}\right)$, and vulnerable by AOO value $\left(124 \mathrm{~km}^{2}\right)$. This difference results mainly from the IUCN default cell used for AOO, which restricts the area of occurrence of the species. Since $M$. setosa is a somewhat common species, particularly in Central Brazil, we chose to apply the least concern category to this species. It is important to stress, though, that $M$. setosa has been seldom collected on its southern most area of occurrence, where a large part of the original vegetation has been destroyed.

Representative specimens examined: BRAZIL. DISTRITO FEDERAL: Brasília, Folha SD-23-Y-C, Reserva Ecológica do IBGE, entre a guarita e a sede, aprox. $15^{\circ} 57^{\prime} 1^{\prime \prime} \mathrm{S}, 47^{\circ} 52^{\prime} 1^{\prime \prime} \mathrm{W}$, aprox. $1100 \mathrm{~m}$ elev., 14 February 2009, fr., M.A. Silva \& F.C. Pinheiro 6957 (IBGE!). GOIÁS: Cristalina, Fazenda Nossa Senhora de Fátima (fundo de alfaville), ca. $1000 \mathrm{~m}$ elev., 15 November 1986, fl., A.F.P de Araújo (UB!). SÃO PAULO: [Araraquara], Araracoara et Batatais, May 1834, fl., L. Riedel 2232 (LE!,NY!).

\section{Mimosa urbica (Barneby) Marc.F. Simon, comb.} \& stat. nov.

Basionym: Mimosa setosa subsp. urbica Barneby (1991: 358). M. setosa subsp. urbica Barneby var. urbica [autonym generated by $M$. setosa subsp. urbica var. urbana Barneby (1991: 358)]. Type: Brazil. Brasília: near Setor Industrial, 1050 m, 30 December 1965, fl., H.S. Irwin et al. 9713 (holotype: UB!; isotypes: G!, K!, LE!, NY!, P!, R!, S!, US!). Mimosa setosa subsp. urbica var. urbana Barneby (1991: 358). syn. nov. Type: Brazil. Distrito Federal: Estação de Biologia da Universidade de Brasília, 20 Fev 1969, fl., Heringer 11770 (holotype UB!, isotype: NY!)

Figs. $1-6 ; 8 ; 14$

Shrubs or subshrubs $0.1-1(-2[?]) \mathrm{m}$, prostrate or ascending, probably also forming patches of tangled stems; unarmed. Indumentum composed of simple trichomes, filiform setae, and stipitate glandular setae with a clavate head, the latter generally absent from vegetative parts and fruits and, when present, not abundantly so; branches, stipules, petiole, rachis, rachillas and peduncles pubescent with simple trichomes ca. $0.2 \mathrm{~mm}$ long, patent filiform setae (0.7)1.5-5 mm long, and very rarely also patent glandular setae ca. $0.3 \mathrm{~mm}$ long; leaflets ciliate with trichomes, filiform setae (sometimes absent) and very rarely also glandular setae. Leaves 10-22-jugate; stipules $12 \mathrm{~mm} \times 1.2-2$ $\mathrm{mm}$, lanceolate-acuminate to narrowly triangular, plane, caducous; petioles 24-28 mm long, 2.2-2.5 $\mathrm{mm}$ diam., grooved on adaxial surface, pulvinus 5-5.5 mm long; rachis 20-22 cm long, 1.5-1.6 $\mathrm{mm}$ diam., grooved on adaxial surface and with a

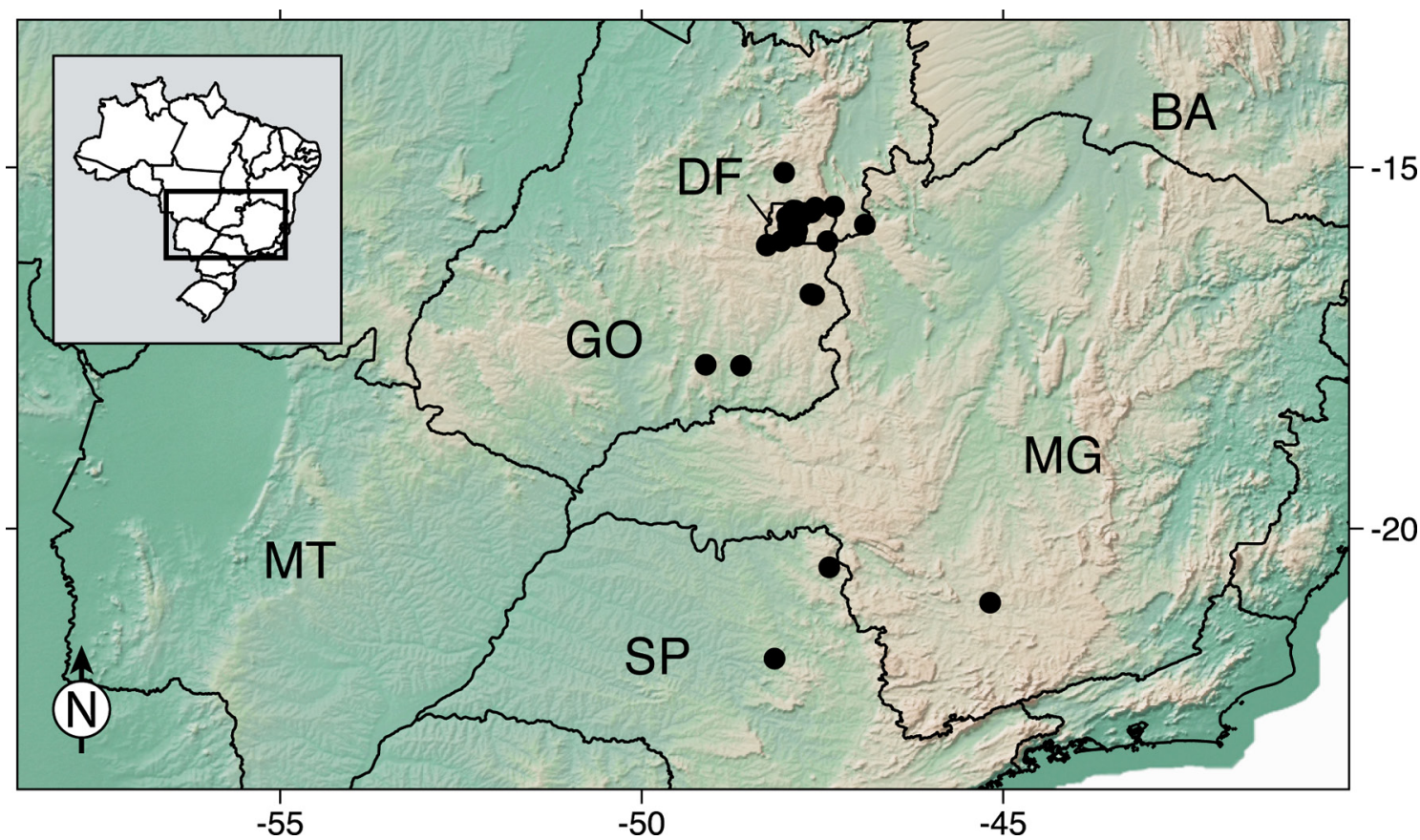

Figure 13 - Distribution of Mimosa setosa. $(\mathrm{BA}=$ Bahia state; $\mathrm{DF}=$ Distrito Federal; $\mathrm{GO}=$ Goiás state; $\mathrm{MG}=\mathrm{Minas}$ Gerais state; $\mathrm{MT}=$ Minas Gerais state; $\mathrm{SP}=$ São Paulo state). 
laminar projection 1.8-2.1 mm long between each pinnae pair, terminal projection $4.5-5 \mathrm{~mm}$ long, linear; basal rachillas 31-43 $\mathrm{mm}$ long, medial rachillas 48-66 mm long, distal rachillas $42-52$ $\mathrm{mm}$ long, all $0.4-0.5 \mathrm{~mm}$ diam., $9.5-10 \mathrm{~mm}$ apart; leaflets $4.8-6 \times 1.9-2.1 \mathrm{~mm}$, in 23-26 pairs on basal rachillas, in 23-30 pairs on medial rachillas, in 22-28 pairs on distal rachillas, narrowly-oblong, inequilateral, $1.2-1.4 \mathrm{~mm}$ apart, apex rounded, mucronulate, base oblique, subcordate, roundedtruncate, venation 4-palmate, primary veins prominent on abaxial surface; paraphyllidia $0.6-1.2$ $\times 0.1-0.2 \mathrm{~mm}$, subulate. Inflorescences arranged in fascicles of 2 racemes distributed along frondose, terminal double-racemes, exserted from foliage, sometimes organized in a frondose, paniculate synflorescence. Racemes 19-24 × 11-13 mm, elliptic, associate leaf developing after anthesis, fully expanded when fruits mature; peduncles
2.2-3 mm long; floral bracts $6.5-7.5 \times 1-1.5$ $\mathrm{mm}$, narrowly acuminate-spatulate, cymbiform, pubescent with trichomes and filiform setae $1.3-1.7 \mathrm{~mm}$ long, prominently present on margins; flowers 4-merous, diplostemonous, basal flowers only staminate; pedicel $0.1-0.2 \mathrm{~mm}$ long; calyx $0.4-0.6 \mathrm{~mm}$ long, cupulate, lobes absent, rim ciliate with plane setae $1.3-2 \mathrm{~mm}$ long, laterally fused at base, tube glabrous; corolla 5.3-6 mm long, infundibuliform, tube glabrous, lobes 1.7-2.1 $\times$ $1.3-1.5 \mathrm{~mm}$, ovate, 1-nerved, vein apex prominent, pubescent with filiform setae $0.5-0.8 \mathrm{~mm}$ long, and glandular setae ca. $0.1 \mathrm{~mm}$ long, indumentum not concealing lobes surface; filaments 18-22 $\mathrm{mm}$ long, glabrous, fused $0.5-0.6 \mathrm{~mm}$ at base, pink; anthers $0.7-0.8 \times 0.7-0.8 \mathrm{~mm}$, glabrous; ovary $1.5-1.7 \times 0.7-0.8 \mathrm{~mm}$, compressed, elliptic, tomentose with filiform setae ca. $1 \mathrm{~mm}$ long and glandular setae ca. $0.4 \mathrm{~mm}$ long, stipe $0.2-0.3 \mathrm{~mm}$
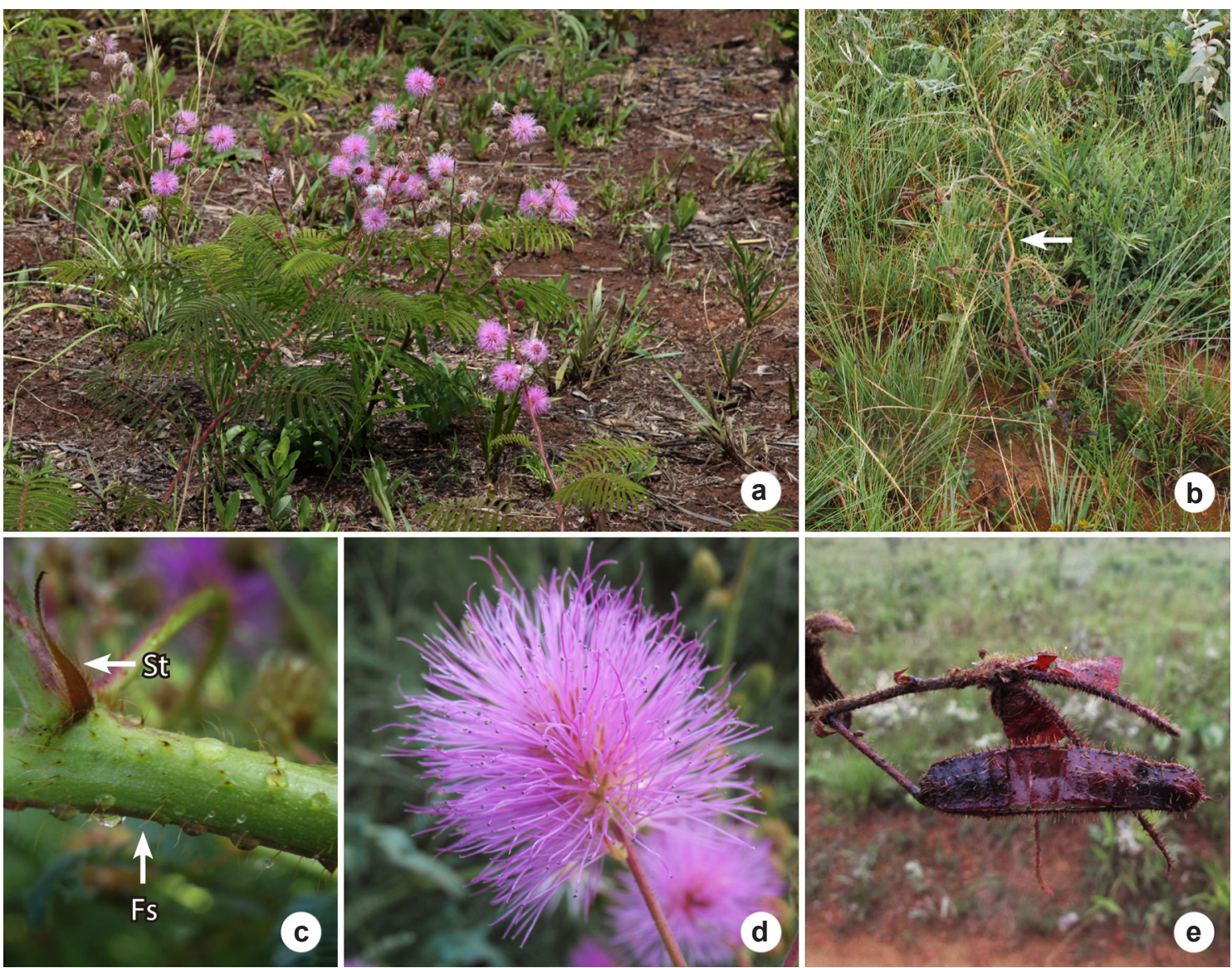

Figure 14 - Mimosa urbica - a-b. habit; a. individual with assurgent stems; b. individual with prostrate stems; c. branch with narrowly triangular stipule (St) and filiform setae (Fs), but lacking glandular setae; d. raceme; e. fruits. All photographs by L.M. Borges, except for a, by M.F. Simon. 
long, glabrous; style 17-20 mm long, glabrous; stigma porate, glabrous. Craspedium 28-43 × 9-12 $\mathrm{mm}$, narrowly oblong, papery, dark-brown, apex obtuse to rounded, obliquely aristate, base cuneate, completely pubescent with trichomes (sometimes lacking on old fruits) and hirsute with filiform setae $2-2.5 \mathrm{~mm}$ long and glandular setae $0.4-1.8$ $\mathrm{mm}$ long, the latter more abundant; pedicel $0.8-2.3$ $\times 1.3-1.4 \mathrm{~mm}$; replum $0.8-1.3 \mathrm{~mm}$ wide; valves partially and irregularly breaking long after seed liberation; seeds not seen.

Mimosa urbica differs from M. setosa and $M$. paludosa by the presence of a thickened underground system (vs. absence); the prostrate habit ( $v s$. erect); and lack of prickles ( $v s$. present in $M$. paludosa and very rarely occurring in $M$. setosa).

Barneby (1991) indicates that Mimosa setosa var. urbica and $M$. setosa var. urbana differ in habit, the former being an "ascending shrub" and the latter a "trailing subherbaceous plant". Field observations indicate that the distal portion of those trailing subshrubs is usually erect, reaching about $50 \mathrm{~cm}$ long and exposing the synflorescence axis above ground level. Hence, the erect disposition of M. setosa var. urbica may be the expression of a mature plant regenerating from damage to its aerial part, most likely by fire, a common ecological factor in the Brazilian Cerrado. Glandular setae on vegetative organs are lacking in most $M$. urbica collections, and may be useful as an identification tool. However, some specimens do present this indumentum type, and in consequence it cannot be used as a diagnostic character state.

Besides the differences in habit mentioned above, Barneby (1991) also distinguished the varieties of Mimosa setosa subsp. urbica by the number of pinnae and leaflet pairs (the latter related to pinnae length). $M$. setosa var. urbica presents 15-23 pinnae pairs with 28-42 pairs of leaflets, while $M$. setosa var. urbana has 4-12 and 16-22 pairs, respectively. Leaves with more pinnae pairs usually also have more pairs of leaflets, but many specimens present intermediate numbers, blurring any distinction between the varieties (e.g., Kirkbride 3101 [pinnae: 18; leaflets 28]; Jouvim 472 [pinnae: 18; leaflets 27]; Duarte 9958 [pinnae: 14; leaflets 28]; Pereira 4630 [pinnae: 15; leaflets $25])$. Hence, those varieties are here treated as a single taxonomic entity at species level. On the other hand, the distinction between M. setosa and the proposed M. urbica, as herein circumscribed and highlighted above, is also related to habit. So far we have not found any examples of transitions between different habit types, such as those, occurring in Mimosa; therefore we considered difference in habit as a distinctive character between these species. If experimental work or more exhaustive field studies demonstrate that this is the case, and no other distinctive characters are discovered, then the habit of $M$. setosa, M. setosa var. urbica, and M. setosa var. urbana could be understood as a clinal variation within a single species.

Mimosa urbica is endemic to the Distrito Federal, Brazil, where it occurs in natural open formations of cerrado between 900 and $1100 \mathrm{~m}$ in elevation and in cerrado remnants in urbanized areas.

EN. Both EOO of $914.765 \mathrm{~km}^{2}$ and AOO of $44 \mathrm{~km}^{2}$ place Mimosa urbica in the endangered category. The species is also subject to loss of habitat from urban expansion, even though many areas in the surroundings of Brasília are protected as either natural or historical sites.

Representative specimens examined: BRAZIL. DISTRITO FEDERAL: Brasília, Parque Olhos D'Água - lado oposto à Lagoa dos Sapos, 1544'40"S, 47053'16"W, 1050 m elev., S.M. Fank-de-Carvalho 30 (UB!); Brasília, Planaltina, Estação Ecológica das

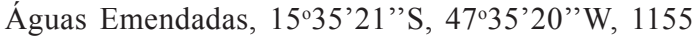
m elev., 15 April 2005, L.P. Queiroz 10302 (HUEFS); Parque Nacional de Brasília, Próximo à área do Exército, $15^{\circ} 53^{\prime}$ 'S, 47056'W, 21 January 1991, P.C.M. Ramos 561 (ESA!, UB!).

\section{Concluding Remarks}

Delimitation of species was not based on a particular morphological feature, but was established based on combinations of different character states from multiple organs (see characterization for each species and the matrix available on Morphobank). However, as found by Barneby (1991), the presence on different organs of epidermal projections, such as aculei, trichomes and setae, played a major role in taxon recognition. Not surprisingly, such structures are frequently used for species delimitation within Mimosa.

Most species have narrow distribution ranges, which are included either in the area of distribution of Mimosa setosa or M. paludosa, or even were both occur together (e.g., M. urbica). It has been suggested elsewhere (Borges et al. 2014) that M. paludosa, which has the largest distribution and morphological plasticity of all species in the $M$. setosa complex, could be 
acting as a species pump (see Knapp 2011), in which regional subsets of the widespread species would diverge into new species through different biological processes. In this scenario, phylogenetic analysis of multiple accessions of each taxa involved in the complex would show M. paludosa to be paraphyletic in respect to other taxa (Borges et al. 2014). Nonmonophyly of widespread species is hypothesized to occurs in the cerrado (Pennington \& Lavin 2016), but, even though a recent phylogenetic analysis reinforces our taxonomic revision of the $M$. setosa complex (Borges 2014), lack of resolution on shallow nodes and intraspecific sampling precludes inferences about speciation modes. Nonetheless, with improvement of phylogenetic data, the $M$. setosa complex and related species could be interesting candidates for studies combining phylogeny, geography and speciation (e.g., Graham et al. 2004; see also Losos \& Glor 2003).

Even though the changes herein proposed for the Mimosa setosa complex alter the rank of taxa recognized by Barneby (1991), their circumscriptions barely differ from those he established. Exceptions are the synonymization of M. setosa var. pseudomelas under M. setosa, M. setosa var. metadenotricha under M. paludosa and $M$. setosa var. urbana under M. urbica, which reduces the total number of least inclusive taxa from nine to six.

This reduction in the number of taxa, which is based on the association of field observations, examination of a more complete set of collections, and the application of the Phylogenetic Species Concept, improves the classification of the Mimosa setosa complex and the genus Mimosa as a whole. Moreover, the circumscription presented here is supported by the topology obtained in a more recent phylogenetic analysis (Borges 2014) and by geography. Taxon limits proposed here reflect more accurately the diversity of the genus by restricting recognition of strong morphological differences to species level.

Some nomenclatural rank changes have been made for Mimosa after the 1991 treatment of Barneby (e.g., Grether 2000). However, the approach adopted here is a step toward establishing a classification for Mimosa devoid of infraspecific taxa. Such a scheme would allow recognition of least inclusive taxonomic units which would be, if not precisely, at least more accurately comparable. This could enhance the quality of comparative studies within the genus, which largely rely on a robustly established taxonomy.

\section{Acknowledgments}

We thank herbaria curators for allowing access to Mimosa collections and loan of specimens; J.G. Rando and G.P. Lewis for kindly sharing their photographs; Renato Mello-Silva for help with Pohl's itinerary; Laura Montserrat for the illustrations; as well as G.P. Lewis, two anonymous reviewers and the editor Marli Pires Morim for their contributions to the improvement of this work. LMB's research on Mimosa was supported by FAPESP (2010/11093-1), FAPESP (2013/13709-8) and partially by NSF-DBI-074975 grants. CNPq supported MFS and JRP.

\section{References}

Bachman, S.; Moat, J.; Hill, A.W.; de Torre, J. \& Scott, B. 2011. Supporting Red List threat assessments with GeoCAT: geospatial conservation assessment tool. ZooKeys 126: 117-26. DOI: 10.3897/ zookeys.150.2109.

Barneby, R.C. 1991. Sensitivae censitae: a description of the genus Mimosa Linnaeus (Mimosaceae) in the New World. Memoirs of the New York Botanical Garden 65: 1-835.

Barneby, R.C. \& Grimes, J.W. 1996. Silk Tree, Guanacaste, Monkey's Earring - A generic system for the synandrous Mimosaceae of the Americas. Part I - Abarema, Albizia, and Allies. Memoirs of the New York Botanical Garden 74: 1-292.

Barroso, G.M.; Morim, M.P.; Peixoto, A.L. \& Ichaso, C.L.F. 1999. Frutos e sementes: morfologia aplicada à sistemática de dicotiledôneas. Editora UFV, Viçosa. 443p.

Bentham, G. 1841. Notes on Mimoseae, with a short Synopsis of Species. Journal of botany: being a second series of the Botanical miscellany 4: 243-392.

Bentham, G. 1842. Notes on Mimoseae, with a short Synopsis of Species. Journal of botany: being a second series of the Botanical miscellany 4 : 393-418.

Bentham, G. 1845. Notes on Mimoseae, with a Synopsis of Species. The London journal of botany: containing figures and descriptions of such plants as recommend themselves by their novelty, rarity, history, or uses: together with botanical notices and information and and occasional portraits and memoirs of eminent botanists 4: 580-622.

Bentham, G. 1846. Notes on Mimoseae, with a Synopsis of Species. The London journal of botany: containing figures and descriptions of such plants as recommend themselves by their novelty, rarity, history, or uses: together with botanical notices and information and and occasional portraits and memoirs of eminent botanists 5: 75-108; Tab. I. 
Bentham, G. 1875. Revision of the Suborder Mimoseae. Transactions of the Linnean Society 30: 335-644; Tab. 66-70.

Bentham, G. 1876. Leguminosae III. Mimoseae. In: Martius, C.F.P. von; Eichler, A.W. \& Urban, I. Flora Brasiliensis. Leipzig, Munchen, Wien. Vol. 15, pars II, pp. 257-520. Fasc LXX; tab 67-138.

BFG 2015. Growing knowledge: an overview of seed plant diversity in Brazil. Rodriguesia 66: 1085-1113. DOI: $10.1590 / 2175-7860201566411$.

Borges, L.M. 2014. Phylogeny and systematics of Mimosa L.: M. ser. Pachycarpae Benth. and M. ser. Setosae Barneby. Universidade de São Paulo, São Paulo. 269p.

Borges, L.M. \& Pirani, J.R. 2014. Busted ghosts: Rediscovery of supposedly destroyed types of Brazilian Mimosa (Leguminosae, Mimosoideae). Phytotaxa 177: 207-220.

Borges, L.M.; Simon, M.F. \& Pirani, J.R. 2014. The census continues: Two new montane species of Mimosa (Leguminosae Mimosoideae) from Southeastern Brazil. 177: 35-48.

CRIA 2015. Species Link, geoLoc tool. Available at $<$ http://splink.cria.org.br/geoloc $>$. Access on September 1, 2015.

Dahmer, N.; Simon, M.F.; Schifino-Wittmann, M.T.; Hughes, C.E.; Miotto, S.T.S. \& Giuliani, J.C. 2010. Chromosome numbers in the genus Mimosa L.: cytotaxonomic and evolutionary implications. Plant Systematics and Evolution 291: 211-220. DOI: 10.1007/s00606-010-0382-2.

Davis, J.I. \& Nixon, K.C. 1992. Populations, Genetic Variation, and the Delimitation of Phylogenetic Species. Systematic Biology 41: 421-435.

Dutra, V.F. \& Garcia, F. 2012. Two new species and one new variety of Mimosa sect. Habbasia (Leguminosae: Mimosoideae) from Central Brazil. Kew Bulletin 68: 1-9.

Graham, C.H.; Ron, S.R.; Santos, J.C.; Schneider, C.J. \& Moritz, C. 2004. Integrating phylogenetics and environmental niche models to explore speciation mechanisms in dendrobatid frogs. Evolution 58: 1781-93. DOI: 10.1111/j.0014-3820.2004. tb00461.x.

Grether, R. 2000. Nomenclatural changes in the genus Mimosa (Fabaceae, Mimosoideae) in Southern Mexico and Central America. Novon 10: 29-37.

Harris, J.G. \& Harris, M.W. 2001. Plant Identification Terminology. $2^{\text {nd }}$ ed. Spring Lake Publishing, Spring Lake. 206p.

Henderson, A. 2004. A multivariate analysis of Hyospathe (Palmae). American Journal of Botany 91: 953-965.

Henderson, A. 2005a. A multivariate study of Calyptrogyne (Palmae). Systematic Botany 30: 60-83.

Henderson, A. 2005b. The methods of herbarium taxonomy. Systematic Botany 30: 456-459.
Henderson, A. 2011. A revision of Geonoma (Arecaceae). Phytotaxa 17: 1-271.

Hennig, W. 1968. Elementos de una Sistemática Filogenética. EUDEBA, Buenos Aires. 353p.

Knapp, S. 2011. Rarity, species richness, and the threat of extinction - Are plants the same as animals? PLoS biology 9: e1001067. DOI: 10.1371/journal. pbio. 1001067.

Linnaeus, C. 1753. Species plantarum, exhibentes plantas rite cognitas, ad genera relatas, cum differentii specificis, nominibus trivialibus, synonymis selectis, locis natalibus, secundum systema sexuale digestas. Laurentius Salvius, Stockholm. 1200p

Losos, J.B.L. \& Glor, R.E. 2003. Phylogenetic comparative methods and the geography of speciation. Trends in Ecology and Evolution 18: 220-227.

Luckow, M. 1995. Species concepts: assumptions, methods, and applications. Systematic Botany 20: 589-605.

Luckow, M. 2005. Tribe Mimoseae. In: Lewis, G.; Schrire, B.; Mackinder, B. \& Lock, M. (eds.). Legumes of the world. Royal Botanic Gardens, Kew. Pp. 163-183.

Maddison, W.P. \& Maddison, D.R. 2015. Mesquite: a modular system for evolutionary analysis. Version 2.75. Disponível em $<$ http://mesquiteproject.org $>$.

Martius, K.F.P. von 1838. Martii Herbarium flora Brasiliensis. Flora oder Botanische Zeitung: welche Recensionen, Abhandlungen, Aufsätze, Neuigkeiten und Nachrichten, die Botanik betreffend, enthält / herausgegeben von der Königl. Botanischen Gesellschaft in Regensburg. 21: 49-96.

McDade, L.A. 1995. Species concepts and problems in practice: insight from botanical monographs. Systematic Botany 20: 606-622.

Nixon, K.C. \& Wheeler, Q.D. 1990. An amplification of the phylogenetic species concept. Cladistics 6:211223. DOI: 10.1111/j.1096-0031.1990.tb00541.x.

Pennington, R.T. \& Lavin, M. 2016. The contrasting nature of woody plant species in different neotropical forest biomes reflects differences in ecological stability. New Phytologist 210: 25-37.

QGIS Development Team. 2015. Quantum GIS geographic information system. Version 2.10.1. Open source geospatial foundation project. Disponível em $<$ http://qgis.org $>$.

Radford, A.E.; Dickison, W.C.; Massey, J.R. \& Bell, C.R. 1976. Vascular plant systematics. Harper and Row, New York. 891p.

Sereno, P.C. 2007. Logical basis for morphological characters in phylogenetics. Cladistics 23: 565-587.

Simon, M.F.; Hughes, C.E. \& Harris, S.A. 2010. Four new species of Mimosa (Leguminosae) from the central highlands of Brazil. Sistematic Botany 35: 277-288.

Simon, M.F.; Grether, R.; de Queiroz, L.P.; Särkinen, T.E.; Dutra, V.F. \& Hughes, C.E. 2011. The evolutionary history of Mimosa (Leguminosae): toward a phylogeny of the sensitive plants. 
American Journal of Botany 98: 1201-1221. DOI: 10.3732/ajb.1000520.

Taubert, P.H.W. 1896. Beiträge zur Kenntnis der Flora des centralbrasilianischen Staates GoyazBeitrfige zur Kenntnis der Flora des cenlralbrasilianiscben Staates Goyaz. Mit einer pflanzengeographischen Skizze von E. Ule. (Mit Tafel II u. Ill). Botanische Jahrbücher fur Systematik, Pflanzengeschichte und Pflanzengeographie 21: 402-457.

Thiers, B [continuously updated]. Index Herbariorum: A global directory of public herbaria and associated staff. New York Botanical Garden's Virtual Herbarium. Available at $<$ http://sweetgum. nybg.org/ih/>. Access 25 January 2016.
Villiers, J.-F. 2002. Tribe Mimoseae. In: DuPuy, D. J.; Labat, J.-N.; Rabevohitra, R.; Villiers, F.-F.; Bosser, J. \& Moat, J. (eds.). The Leguminosae of Madagascar. Royal Botanic Gardens, Kew. Pp. 159-223.

Weberling, F. 1989. Morphology of flowers and inflorescences. Cambridge University Press, Cambridge, New york, Port Chester, Melbourne, Sydney. 405p.

Wheeler, Q.D. \& Platnick, N.I. 2000. The phylogenetic species concept (sensu Wheeler and Platnick). In: Wheeler, Q.D. \& Meier, R. (eds.). Species concepts and phylogenetic theory. A debate. Columbia University Press, New York. Pp. 55-69.

\section{List of numbered exsiccatae}

Specimens arranged by collector's last name in alphabetic order, followed by collection number in increasing order and with the species number between parentheses. Unnumbered, but studied, specimens are not presented in order to avoid errors. Species numbers follow the taxonomic treatment: 1. Mimosa granitica (Barneby) L.M. Borges; 2. M. neonitens (Benth.) L.M. Borges; 3. M. paludosa Benth.; 4. M. rupigena (Barneby) L.M. Borges; 5. M. setosa Benth.; 6. M. urbica (Barneby) Marc.F. Simon.

Albuquerque, V.R. 5 (5). Allem, A. 422 (6); 449 (5). Alves, M.S. 17 (5). Amaral, A.G. 2308 (5); 2309 (5). Amorim, E.H. 446 (2); 472 (2); 697 (2). Anderson, W.R. 8672 (3); 9540 (3). Andrade, M.J.G. 334 (3). Antunes, N.B. 29095 (3). Arantes, A.A. 178 (3). Araújo, D.E. 1 (5). Araújo, G.M. 221 (3); 231 (3); 1829 (3); 3042 (3); FEEP 231 (3). Arruda, R. 206 (2). Assis, M. 1250 (3). Assis, M.A. 1148 (3). Assis, V. 88 (3). Barbosa, D.A.A. 1926 (3). Barbosa, E. 2042 (3). Barbosa, M. 2326 (3). Barreto, K.D. 2414 (3). Barreto, M. 6525 (3). Barreto, R. CFCR 12097 (3). Barros, M.A.G. 2264 (5). Belém, R.P. 85 (5); 1941 (5). Bocage, A. 1079 (3). Borges, L.M. 116 (3); 370 (4); 390 (3); 409 (3); 434 (3); 485 (6); 489 (6); 511 (1); 515 (6); 553 (1); 566 (3); 603 (1); 619 (5); 697 (3); 1008 (5); 1025 (6); 1027 (2). Botelho, M. 16 (5); 17 (5); 18 (5); 19 (5); 20 (5); 57 (5); 58 (5); 59 (5); 142 (3); 146 (3). Brito, D.S. 150 (5). Burchell, W.J. 5452 (5); 5968 (3). Carneiro, J. 492 (3). Carvalho, A.M.V. 3503 (3); 6513 (3). Castellani, E.D. 185 (3). Castellanos, A. 21756 (5); 26026 (3). Chagas e Silva, F. 1952 (3). Claussen, P. 714 (3); 828 (3); 98[?] (3). Conceição, A.S. 411 (3). Coradin, L. 2353 (5); 8548 (3). Cordeiro, J. 4509 (3). Cordeiro, M.R. 4809 (3). Costa, B. 80 (3). Curran, H.M. 79 (3). Dawson, E.Y. 14780 (1). Duarte, A.P. 9958 (6). Dutra, V. 461 (3). Equipe Jardim Botânico de Brasília 643 (6). Esteves, G.L. CFCR 13401 (3). Fank-de-Carvalho, S.M. 30 (6). Faria, S.M. 442 (3); 1337 (3); 1382 (3); 1771 (3). Farias, R. 127 (3). Felfili, J.M. 92 (2). Ferreira, M.M. 28 (3). Ferreira, R.G.M. 5 (3). Filgueiras, T.S. 1483 (2). Flores, T.B. 759 (3). Fonseca, M.L. 2165 (5); 2454 (3); 3784 (6); 3923 (5). Fontella, J. 1469 (5). Forzza, R.C. 1162 (3). Fothergill, J.M. 92 (3). França, F. 1255 (3). Funch, R. 47 (3); 142 (3). Gajardo, I. 52001 (3). Ganev, W. 1940 (3); 2042 (3); 2283 (3); 2976 (3). Gardner, G. 1942 (3). Gibbs, P.E. 5158 (5). Glaziou, A.F.M. 19123 (3); 19124 (3); 21046 (3); 21047 (3); 21052 (3); 21085 (6); 21097 (5); 21098 (5). Gomes Júnior, J.C. 2443 (5). Gomes, B.M. 207 (5); 385 (3). Gomes, W.V. 22 (5). Gottsberger, G.K. 118-2386 (2). Grillo, A.A. 162 (3). Groppo, M. 1411 (3). Guedes, M.L. 17677 (3); PCD 475 (3). Handro, O. 738 (5). Harley, R.M. 20047 (3); 20071 (3); 22712 (3); 22726 (3); 25771 (3); 28336 (3); PCD 3686 (3). Hatschbach, G. 27302 (4); 37820 (5); 41615 (3); 42242 (3); 44679 (3); 44747 (5); 46486 (3); 46671 (3); 47970 (3); 49667 (4); 50538 
(3); 51036 (3); 52883 (3); 53446 (3); 55855 (5); 56693 (3); 59517 (1); 59632 (3); 60486 (3); 61839 (3); 62154 (3); 62839 (3); 66574 (3); 69421 (5). Hattori, E.K.O. 551 (3). Heringer, E.P. 1050 (5); 1656 (3); 3602 (3); 6196 (5); 7265 (3); 7839 (5); 10320 (6); 11242 (5); 11565 (5); 11566 (6); 11762 (6); 11770 (6); 11770 (6); 12022 (5); 12075 (6); 12141 (3); 12241 (5); 12242 (5); 13029 (5); 13056 (5); 13075 (5); 15377 (5); 15581 (5); 16862 (6); 17146 (5); 18497 (5); 8763957 (6). Hind, D.J.N. PCD 4268 (3). Hoehne, F.C. 20327 (3); 2571 (3). Hoehne, W. 6008 (3). Irwin, H.S. 5315 (3); 5938 (5); 6062 (5); 6856 (3); 8785 (3); 8911 (5); 9276 (1); 9713 (6); 10556 (5); 11069 (3); 11094 (6); 11386 (6); 12100 (5); 12834 (1); 12944 (1); 12980 (5); 15499 (3); 15523 (3); 15798 (3); 17686 (3); 17728 (3); 18104 (3); 19420 (5); 20751 (3); 21924 (4); 23775 (3); 25174 (3); 25551 (2); 25760 (3); 26695 (6); 27440 (3); 28567 (3); 30547 (3); 31721 (3); 32231 (1); 32231 (1); 32523 (3); 33045 (1). José, M. 104 (3). Kirkbride Jr., J.H. 1454 (5); 3101 (5); 3665 (5); 5449 (5); 5506 (6). Kollman, L. 4264 (3). Krapovickas, A. 32594 (3); 33177 (6). Krieger, P.L. 14064 (3). Lasseigne, A.A. 4359 (3). Leitao Filho, H.F. 1793 (3); 1998 (3); 12508 (5). Lewis, G.P. 907 (3); 1979 (3); CFCR 6786 (3). Lima H.C. (3). Lima, O.B. 1 (6). Lobato, L.C.B. 2253 (3). Loefgren, A. 885 (5). Lombardi, J.A. 1902 (3); 4040 (3); 4925 (3); 5223 (3). Luetzelburg, P. 36 (3). Lund, P.W. 5 (5). Luz, A.A. 118 (3). Macedo, A. 1100 (3); 1768 (3); 1787 (3); 3414 (5); 4285 (2). Magalhães, G.M. 19266 (2). Maguire, B. 57153 (5). Marcondes Ferreira, W. 1632 (3). Martinelli, G. 11213 (3); 11297 (3). Martins, M.V. 48 (5). Martius, C.F.P. 475 (3); 476 (3). Mello Filho, L.E. 16 (5); 5105 (5). Mello-Silva, R. CFCR 9955 (3); 1445 (3). Mello, L.E. 2660 (3). Melo, E. 1265 (3). Mendes, S. 760 (3). Mendonca, C.V. 204 (3); 206 (3); 282 (3); 1141 (4). Mendonça, R.C. 1230 (2); 1315 (3); 5629 (5). Meneses Filho, L.C.L. 11 (3). Meyer, S.T. 14996 (3). Miranda Silva, E.B. 418 (3). Mizoguchi, K. 2233 (3). Morais, A.T. 5 (3). Mori, S.A. 12417 (3); 12250 (3). Nascimento, F.H.F. 192 (3). Neto, E.T. 1520 (3); 2061 (3). Neto, E.T. 224 (5); 2061 (3). Pando, L. 1 (3). Passos, F.B. 25 (5). Pedralli, G. 14772 (3); 14933 (3); 14934 (3); 14977 (3). Pereira, E. 7546 (3). Pereira, A.B. 2 (5). Pereira, B.A.S. 556 (5). Pereira, E. 4630 (6); 7268 (6). Pereira, F.B. 638 (3). Pilger, R. 617 (3). Pio, L.C. 23 (3). Pirani, J.R. 2233 (3). Pirani, J.R. CFCR 13050 (3). Pires, A. 170 (6). Pires, J.M. 9529 (3); 57153 (5); 58053 (3). Pohl, J.B.E. 390 (3); 664 (2); 846 [=D.1409] (5). Pott, A.10369 (3); 12417 (3). Prance, G.T. 59607 (3). Proença, C.E.B. 1332 (5); 1428 (5); 1540 (3); 1589 a (5); 1647 (5); 2003 (3); 2022 (5); 2049 (3); 2122 (5); 2360 (3); 3124 (?); 4222 (3). Queiroz, L.P. 5019 (3); 9192 (3); 10302 (6); 10341 (3); 10388 (3). Ramalho, R.S. 2233 (3). Ramos, A.E. 129 (6); 484 (5). Ramos, P.C.M. 197 (5); 561 (6). Ratter, J.A. 3204 (3). Regnell, A.F. III 506 (3); III 506 a (3); III 510 (5); III 510 x (5). Rezende, J.M. 264 (6). Ribas, O.S. 7612 (3). Ribeiro, T. 302 (3). Riedel, L. 7 (3); 384 (3); 584 (3); 585 (3); 663 (3); 1306 (3); 2232 (5); 2232 (5). Rivera, V.L. 21 (3). Rizzo, J.A. 6539 (5). Rodarte, A. 3A (3). Rodrigues-da-Silva, R. 955 (5). Roque, N. 1431 (3). Rosa, N.A. 5200 (3). Rosa, P.O. 162 (3). Roth, L. 1882 (3). Rozza, A. 332 (3). Saint-Hilaire, A.F.C.P. C1 526 (2); C1 719 (1). Samii, M.B. 146 (3). Santos, E. 2283 (5). Santos, J.R. 114 (6). Santos, M.F. 771 (3). Santos, O.H.M. 6 (3). Santos, R.S. 24087 (3). Savassi-Coutinho, A.P. 1313 (3); 1325 (3). Schessl, M. 3384 (3). Semir, J. 01/153 (4); 01/154 (4);1153 (4); 1154 (4); 1160 (4); CFCR 179 (4). Serafim, H. 353 (3). Shepherd, G.J. 7424 (3). Silva, F.C.F. 46 (3). Silva, G.P. 2199 (6); 5555 (6); 7359 (3); SVW 3075 (3). Silva, M.A. 866 (5); 2539 (5); 5650 (5); 5712 (5); 6839 (5). Silva, M.G. 4632 (3). Silva, N.T. 57181 (6). Silva, S.S. 112 (3); 274 (5). Simon, M.F. 44 (5); 61 (3); 100 (5); 300 (5); 306 (3); 435 (3); 444 (3); 666 (3); 683 (5); 725 (3); 730 (6). Soares-Silva, L.H. 992 (1). Sobrinho, J.S. 245 (3). Sousa, J.S. 100 (3). Souza, J.P. 2684 A (3). Souza, V.C. 8453 (3); 22612 (3); 26078 (3). Stehmann, J.R. 2527 (3). Taxonomy Class of Univ. de Brasilia 204 (5). Teixeira, W.A. 25034 (3). Tsugaru, S. B-84 (5); B-142 (3); B-184 (5). Ule, E.H.G. 4 (5); 6954 (3). Vieira, R.C. 212 (3). Weddell, M.A. 1870 (2). Winder, J.A. 149/A (3); 153 (3); 158 (3); 163 (3); $173 /$ A (3); 193/A (3); 194/A (3). Zappi, D.C. CFCR 9809 (3). 